Yayın Geliş Tarihi: $\quad$ 31.03.2016

Yayın Kabul Tarihi: 04.01 .2018

Online Yayın Tarihi: 20.04.2018
Dokuz Eylül Üniversitesi İktisadi ve İdari Bilimler Fakültesi Dergisi Cilt:33, Sayı:1, Yıl:2018, ss. 1-38

\title{
Psikolojik Sözleşme İhlali ile Hissettirdiklerinin Örgütsel Özdeşleşme, İş Tatmini ve İşten Ayrılma Niyeti Üzerine Etkileri
}

\author{
Şebnem ASLAN ${ }^{1}$
}

\author{
Seda UYAR ${ }^{2}$
}

$\ddot{O} \mathbf{z}$

Bu çalı̧̧mada psikolojik sözleşme ihlali ile hissettirdiklerinin örgütsel özdeşleşme, iş tatmini (iç iş tatmini-dış iş tatmini) ve işten ayrılma niyeti üzerindeki etkisi araştırllmış̧ır. Araştırma Türkiye' deki İ̧ Anadolu ve Akdeniz bölgesinden 4 ildeki 4hastanede 300 sağllk çalışanı ile yapılmış̧ır. Çalışmanın sonucunda "algılanan psikolojik sözleşme ihlali" ile "örgütsel özdeşleşme" arasında negatif bir iliş̧ki tespit edilmişstir. Ayrıca "algılanan psikolojik sözleşme ihlalinin hissettirdikleri" ile "dlş iş tatmini", "iç iş tatmini" ve "iş̧ten ayrılma niyeti" arasında da negatif ilişki bulunmuştur. Diğer sonuçlar çalışmada ayrıntılı olarak verilmişstir.

Anahtar Kelimeler: Algılanan Psikolojik Sözleşme, Algılanan Psikolojik Sözleşme İhlalinin Hissettirdikleri, Örgütsel Özdeşleşme, İş Tatmini (dlş ve iç), İșten Ayrllma.

JEL Siniflandirma Kodları: I1, M54.

\section{The Effects of Psychological Contract Breach with Feelings on Organizational Identification, Job Satisfaction and Intention to Quit}

\begin{abstract}
This study investigated the effect of perceived psychological contract breach with the feelings of psychological contract violation upon the organizational identification, job satisfaction (internal job satisfaction-external job satisfaction) and the intention to quit. The study was conducted with 300 healthcare professionals by selecting random samples from 4 hospitals in 4 provinces from the Central Anatolia and Mediterranean regions of Turkey. As a result of the study, a negative relationship was determined between the "perceived psychological contract breach" and "organizational identification". Another negatively significant relationship was determined between the "feelings of psychological contract violation" and " job satisfaction-external", "job satisfaction-internal" and "intention to quit". Other results are given in detail in the study.
\end{abstract}

Keywords: Perceived Psychological Contract Breach, Feelings of Psychological Contract Violation, Organizational Identification, Job Satisfaction (external-internal), Intention to Quit.

JEL Classification Codes: I1, M54.

${ }^{1}$ Doç.Dr., Selçuk Üniversitesi, Sağlık Bilimleri Fakültesi, Sağlık Yönetimi Bölümü, Sağlık Kurumları Yönetimi ve Organizasyonu Anabilim Dalı, sebnemas@hotmail.com

${ }^{2}$ Araş. Gör., Selçuk Üniversitesi, Sağlık Bilimleri Fakültesi, Sağlık Yönetimi Bölümü, Sağlık Kurumları Yönetimi ve Organizasyonu Anabilim Dalı, seda_inan@outlook.com 


\section{GİRIŞ̧}

\section{Ş.ASLAN - S.UYAR}

Günümüzde örgütlerde işgören ile işveren arasında yapılan biçimsel sözleşmeler söz konusu tarafların yükümlülüklerini düzenlemekte ve açıklamakta yetersiz kaldığı için tarafların zihninde olan fakat yazılı halde olmayan psikolojik sözleşme ortaya çıkmaktadır (Mimaroğlu, 2008: 48). Psikolojik sözleşme kavramı, işgörenlerin örgütlerine, örgütlerin de işgörenlerine karşı yerine getirmek zorunda oldukları yükümlülüklere dair işgörenlerin sahip olduğu algılara işaret etmektedir ve bu yükümlülüklerin yerine getirilmemesi de psikolojik sözleşme ihlali kavramını ortaya çıkarmaktadır (Levinson, 1965: 373). Psikolojik sözleşme karşılıklı beklentilere yönelik algıları içermektedir ve işe alımın ilk aşamasında çalışma ilişkilerine dâhil olmaktadır (Didikli, 2013: 118). Örgütlerin içinde bulunduğu dış çevre koşullarındaki büyük çaplı değişimler, işgörenler ve örgüt arasındaki bu ilişkinin önemini artırmaktadır (Levinson, 1965: 373). Dolayısıyla psikolojik sözleşme ve onun ihlâli, örgütlerde dikkate alınması gereken unsurlardan biri haline gelmektedir.

İşgörenler, psikolojik sözleşme unsurlarının ihlâl edildiğini düşündüklerinde, bu durum onların bazı tutum ve davranışlarını etkileyerek örgüt için tehdit unsuru oluşturabilecek örgütsel sonuçlar doğurmaktadır. Bu davranışlardan biri de iş görenlerin iş ve işin sağladıklarına ilişkin bir algısı ve bu algıya karşılık olarak verdiği duygusal cevap olarak tanımlanan iş tatmini olmaktadır (Luthans,1994:114). İş tatmini, psikolojik sözleşmede var olan beklentilerin karşılanma derecesine işaret ettiği için (Dikici, 2005: 46) özellikle beşeri sermayeye önem veren örgütlerde bu sermayeyi etkin ve verimli kullanabilme adına önemli bir olgu olmaktadır. Psikolojik sözleşme ihlâlinin işgören tutum ve davranışları bağlamında çok önemli bir sonucunu ifade eden iş tatmini, işgörenin psikolojik sözleşme anlamındaki 
Dokuz Eylül Üniversitesi İktisadi ve İdari Bilimler Fakültesi Dergisi Cilt:33, Sayl:1, Yll:2018, ss. 1-38 beklentilerinin ne kadar karşılandığına da işaret etmektedir (Turnley ve Feldman, 1999: 368).

Özellikle bilginin ve bilgiye sahip insanın önemli olduğu çağımızda, insan sermayesinin örgütün sahip olduğu en önemli değer olduğu kabul edilmektedir. Bu sebeple örgütlerin ellerindeki bu değerli sermayeyi yani işgörenlerini kurumda tutması önemli öncelikleri arasında bulunmaktadır (Özdemir ve Yaylı, 2014: 49). Unutulmamalıdır ki işten ayrılma niyetine sahip olmak işten ayrılma gerçekleşmese de hem birey hem de örgüt için işi bırakmaktan çok daha yıkıcı sonuçlara sahip bir durum olarak değerlendirilmektedir (Ar1 vd., 2010:146). Özellikle hizmet sektöründe hizmet dışı sektörlere göre işten ayrılma oranlarının iki kat fazla olması (Buick ve Thomas,2001:304), işten ayrılmayı daha geniş çerçeveyle örgütsel davranış alanında işlenmesi gerekli konu haline getirmektedir.

Hem örgüt hem de işgören bazında yadsınamayacak artılar sağlayan diğer bir olgu örgütsel özdeşleşme olmaktadır. Bireyin kendini örgüte ait hissetmesi anlamına gelen örgütsel özdeşleşme (Hall vd., 1970:176), olumlu bir çok çıktı sağlayabilmekte, ancak olumlu şartlarda var olabilmektedir (Chrobot-Mason, 2003: 39). İşggörenin örgüte katkısı neticesinde fayda gördükçe, bireysel ve örgütsel değerlerin örtüşmesi şeklinde tanımlanan örgütsel özdeşleşme düzeyinin artacağı savunulmaktadır (Hall vd., 1970:176). Bu noktadan hareketle, özdeşleşme düzeyi yüksek işgörenlerin istihdamının işletmelerin stratejik insan kaynakları yönetim faaliyetleri açısından önemli olduğu ifade edilebilmektedir (Polat ve Meydan, 2010: 146).

İşü̈cü kaybının engellenmesi, işgörende ortaya çıkan olumsuz duyguların elimine edilmesi, bunun yerine olumlu duyguların gelişmesi adına gerekli koşulların tespit edilmesi ve örgüt politikalarının buna göre 


\section{S.ASLAN - S.UYAR}

düzenlenmesi gerekmektedir (Özdemir ve Yaylı, 2014: 49). Dolayısıyla, psikolojik sözleşme ihlali ile iş tatmini, işten ayrılma ve örgütsel özdeşleşme arasında bir ilişki ve etkinin var olup olmadığı; var ise bu ilişkinin yönü, kapsamı, detayları ve koşullarının neler olduğu; temel bir araştırma sorusu olarak ortaya konmaya değer görünmektedir. Bu kapsamda çalışmanın alan yazına katkı sağlayacağı düşünülmektedir.

$\mathrm{Bu}$ çerçevede öncelikle kavramlar hakkında kısa bir literatür bilgisi verilerek bu kavramlar arasındaki ilişkiyi inceleyen ve sağlık kurumlarında yapılan araştırmanın sonuçları tartışılacaktır.

\section{LITERATÜR TARAMASI}

\subsection{Alglanan Psikolojik Sözleșme İhlali}

Psikolojik sözleşme, çalışanın kişisel algılarına bağlı olan ve örgüt ile çalışanın karşılıklı olarak yerine getirmeleri gereken yükümlülükleri içermektedir (Walker ve Hutton, 2006: 433). Schein (1980)'e göre, işgörenlerin örgüt, örgütün de işgörenle ilgili olarak biçimsel sözleşme kalıplarının dışında, çeşitli varsayım ve beklentileri olmaktadır (Akt. Seçkin, 2011:3). Bu beklentiler, örgütün değişik kademe ve bölümlerinde işgörenlerin algılarına bağlı olarak birbirinden kısmen ya da tamamen farkl1l1klar gösterebilmekte ve zamana, ihtiyaca, bulunulan konuma, örgütün imkânlarına göre değiş̧iklik içermektedir (Kaldırımcı, 1987: 122-124). İsgören ile örgüt arasındaki beklentilerin sadece yazılı olması beklenmemektedir. Psikolojik sözleşme, örgüt-çalışan ilişkilerindeki biçimsel sözleşmeden daha fazla bir içeriğe sahip olması anlamında, karşılıklı beklentiler ve sonuçlarına ilişkin algıyı temsil etmektedir (Seçkin, 2011:1). Bu alg1, işgörenin örgüt içinde gerekli şartları yerine getirdiğinde, örgütün de kendisine birtakım imkânlar sağlayacağı yönünde güçlü bir inanç geliştirmesi ile ilgili olmaktadır (Doğan ve Demiral, 2009: 55). Bundan 
Dokuz Eylül Üniversitesi İktisadi ve İdari Bilimler Fakültesi Dergisi

Cilt:33, Sayl:1, Yll:2018, ss. 1-38

ötürü psikolojik sözleşme, işgören ve örgüt arasında dile getirilmeyen ve yazılı olmayan karşılıklı beklentileri içermesine rağmen, bireysel olarak işgörenin algısına da bağlı bulunan bir kavram olarak tanımlanmaktadır (Knights ve Kennedy, 2005: 58).

Psikolojik sözleşmenin ihlali, taraflardan birinin karşı tarafa olan yükümlülüklerini yerine getirmede başarısız olması anlamına gelmektedir (Petray-Guillard, 2008: 482). Psikolojik sözleşmenin taraflar açısından önemi, ihlaline ilişkin algıya bağlı olarak gösterilen tepkinin sonuçlarına göre anlaşılmaktadır (Seçkin, 2011: 16; Morrison ve Robinson, 1997: 231). Zhao ve Arkadaşlarına (2007: 650) göre psikolojik sözleşme ihlali, çalışanın duygusal tepkisini tetikleyen önemli bir iş yeri olayı şeklindedir. İhlalin genellikle zarar verme duygusunu artırdığı varsayılmakta ve çalışanın psikolojik sözleşmenin ihlali yönünde algı geliştirmesi örgütsel çıkarları olumsuz etkilemektedir (Chambel ve Oliveria-Cruz, 2010: 113).

\section{2. Örgütsel Özdeşleşme}

Örgütsel özdeşleşme genel olarak; “işgörenlerin, çalıştıkları örgüt ve kurumları tanımakta kullandıkları kavramlarla kendilerini ne seviyede tanımladıklarının bir göstergesi” veya örgüt çalışanlarının kendilerini örgüt özellikleriyle aynı şekilde tanımlama derecesi olarak ifade edilmektedir (Dutton, Dukerich ve Harquail, 1994: 239-240; Hall vd., 1970:176-177 ). Ashforth ve Mael (1989: 22-23) ise özdeşleşmeyi, kişinin kendisini içinde olduğu örgüte ait hissetmesi, örgütün başarı ve başarısızlıklarını kendi başarı ve başarısızlığı olarak algılaması ve örgütün amaçlarıyla bireyin amaçlarının giderek daha fazla bütünleşme ve uyumlaşması süreci olarak tanımlamaktadır. Diğer taraftan örgütsel özdeşleşme, bireyin kendini ifade ettiği kavramlarla örgütün ifade ettiği kavramların benzer olması hali olarak da ifade edilmektedir (Polat ve Meydan, 2010: 160). 


\section{Ş.ASLAN - S.UYAR}

Örgütsel özdeşleşme, yalnız örgütün amaçlarına bağlılık değil, aynı zamanda amaç ve değerlerin gerçekleştirilmesiyle ilgili olarak kendi rolüne ve örgütüne yanlı, duyuşsal bir bağlllığ 1 da ifade etmektedir (Buchanan, 1974: 533). Bireyin örgüt amaçlarına ve değerlerine kuvvetle inanması ve onları kabul etmesi, bireyin örgütsel rolünü oluşturan eylemleri isteyerek yapmasıdır ve bireylerin örgüt üyeliğini sürdürmeye istekli olmaları şeklinde üç ana öğeden oluşmaktadır (Mael ve Asforth, 1995:312; Hall vd.,1970:176-177).

Örgütsel özdeşleşme, sosyal kimliğin özel bir formu şeklinde örgütün amaçlarıyla bireyin amaçlarının giderek daha fazla bütünleşmesi ve uyumlaşması sürecini ifade etmektedir (Ashforth ve Mael, 1989: 22-23). Bireyler, örgütle özdeşleştiklerinde bir bakıma kendilerini örgütle kişileştirmektedirler (Mael ve Asforth, 1995:312). Örgütsel özdeşleşme, örgüt ile dayanışma içinde olmayı, örgüte tutum ve davranışsal olarak destekte bulunmayı ve örgüt üyelerinin paylaştığı ayırt edici niteliklerin algılanmasını içermektedir (Miller vd., 2000: 629).

Psikolojik sözleşme ile örgütsel kimlik arasında pozitif yönlü ilişkiye ilişkin çalışma sonuçlarına da ulaşılmaktadır (Rousseau, 1998: 221). Nitekim bireyler, örgütle özdeşleştiklerinde bir bakıma kendilerini örgütle kişileştirmektedirler (Mael ve Asforth, 1995: 312). Psikolojik sözleşmenin ihlali ve psikolojik sözleşmenin ihlalinin hissettirdikleri durumunda ise örgütsel özdeşleşme arasındaki bu ilişki tersine dönecektir (Epitropaki, 2013: 81). Çünkü psikolojik sözleşme algısı işgörenin çalışma ortamındaki davranışlarında belirleyici bir role sahip olmaktadır (Schein, 1980: 55). Psikolojik sözleşme ihlali yönündeki algı da işgörenin örgüte karşı duymuş olduğu olumlu duygularda bir düşüşe neden olmaktadır (Aselage ve Eisenberger, 2003: 495). Buna dayalı olarak Hipotez 1 geliştirilmiştir: 
Dokuz Eylül Üniversitesi İktisadi ve İdari Bilimler Fakültesi Dergisi Cilt:33, Sayl:1, Yll:2018, ss. 1-38

H1. Algllanan psikolojik sözleşme ihlali ile örgütsel özdeşleşme negatif ilişkilidir.

H2. Algllanan psikolojik sözleşme ihlalinin hissettirdikleri ile örgütsel özdeşleşme negatif ilişkilidir.

\section{3. İş Tatmini}

Luthans’a göre (1994:114) iş tatmini işgörenin iş ve işin sağladıklarına ilişkin bir algııı ve bu algıya karşılık olarak verdiği duygusal cevap olarak tanımlanmaktadır. İşi başarmış olmanın verdiği hoş duygu şeklinde de tanımlanan iş tatmini karşılanmış çalışan beklentilerinin katlanmış değeri olarak nitelendirilmektedir (Locke ve Henne, 1986: 21; Hwang ve Kuo, 2006: 255). İşin kendisi, ücret, yükselme fırsatı, yönetim ve iş arkadaşları olmak üzere iş tatminini etkileyen, işe ilişkin beş iş boyutu bulunmaktadır (Luthans, 1994:114).

İş tatmini işin özelliklerinin değerlendirilmesi sonucu oluşan iş hakkındaki olumlu his şeklinde de ifade edilmektedir (Robbins ve Judge, 2012:77). Ayrıca kişinin mesleki değerlerinin karşılığını veren ve mesleki takdirden kaynaklanan pozitif duygusal bir tutum olarak da tanımlanmaktadır (Morhead ve Griffin, 1996: 126). İş tatmini bireyin normlar, değerler ve beklentiler süzgecinden geçerek işlenen iş ve iş koşullarına ilişkin algılarına karşı geliştirdiği iç tepkilerinden meydana gelmektedir (Schneider ve Snyder, 1975: 318). Diğer bir anlatımla iş tatmini kişinin işindeki rolüne karşı duygusal tepkisidir (Kök, 2006: 293). İş tatmini literatürde iç ve dış tatmin şeklinde yer almaktadır. İç iş tatmini çalışma sırasında hissedilen doyumu ifade etmektedir (Açıkalın, 2011: 240). Başarma duygusu gibi çalışma sırasında hissedilen doyum ise iç iş doyumuna örnek gösterilmektedir (Deniz, 2005:311). Ücret ve ekonomik 


\section{S.ASLAN - S.UYAR}

ödüller gibi çalışmanın sonucunda elde edilen doyum dış iş tatmin olarak ifade edilmektedir (Deniz, 2005:311).

İşgörenler, psikolojik sözleşme unsurlarının ihlâl edildiğini düşündüklerinde, bu durum onların iş tatmini gibi bazı tutum ve davranışlarını etkileyerek değişik örgütsel sonuçları doğurma potansiyeli taşımaktadır (Didikli ve Bayraktaroğlu, 2013: 188). Hâlbuki örgütüyle özdeşleșen çalışanın, örgüt amaçlarını kendi amaçlarıymış gibi benimsemesi ve onların gerçekleştirilmesine çalışması önemli bir tatmin kaynağı olmaktadir (Mael ve Asforth, 1995: 312). Rusbelt, Farrell, Rogers ve Mainous (1988:601), çalışanların iş tatminsizliğine karşı bazı farklı tepkiler geliştirmektedir. İş tatmini işgörenin psikolojik sözleşmeye dair beklentilerinin karşılanma derecesiyle bağlantılı görülmektedir (Dikici, 2005: 46-48; Freese ve Schalk, 1996: 506). Yapılan araştırmalarda psikolojik sözleşmenin ihlali ve hissettirdikleri ile iş tatmini arasında negatif yönlü ilişkiye ulaşılmıştır (Naeem vd.,2014: 251; Didikli ve Bayraktaroğlu, 2013: 190). Bu görüşe dayalı olarak hipotez 3a, hipotez 3b, hipotez 4a ve hipotez 4b geliştirilmiştir:

H3a. Algllanan psikolojik sözleşme ihlali ile dış iş tatmin negatif ilişkilidir.

H3b. Algllanan psikolojik sözleşme ihlali ile iç iş tatmin negatif ilişkilidir.

H4a. Algılanan psikolojik sözleşme ihlalinin hissettirdikleri ile dış iş tatmin negatif ilişkilidir.

H4b. Algılanan psikolojik sözleşme ihlalinin hissettirdikleri ile iç iş tatmin negatif ilişkilidir. 


\section{4. İşten Ayrılma Niyeti}

Cilt:33, Sayl:1, Yll:2018, ss. 1-38

İşten ayrılma niyeti işgörenin istihdam koşullarından tatminsiz olmaları durumunda göstermiş olduğu yıkıcı ve aktif bir eylem olarak tanımlanmaktadır (Rusbelt vd., 1988: 599). İşten ayrılma davranışından önce işgörende işten ayrılma niyeti oluşmakta (Teoman, 2007: 34- 35; Tett ve Meyer, 1993:259) ve bu niyet işgörenin, çalıştı̆̆1 kurumda kalma niyetinin ölçüsünü de göstermektedir (Orbay, 2008: 31). İşten ayrılma niyeti bir işgörenin örgütü bırakma eğilimi şeklinde de tanımlanmaktadır (Ökten, 2008: 35). Genel bir ifadeyle de işgörenin herhangi bir kurumda çalışmak istememe davranışı olarak ifade edilmektedir (Özdevecioğlu, 2004: 98; Weisberg, 1994:4). İşten ayrılma niyeti gerçek işten ayrılmadan farklı olarak işgörenlerin iş yerinde kalmak ya da istifa etmek için kendini değerlendirme niyetleri olarak tanımlanmaktadır (Mobley, 1982: 10). Ayrıca, örgütten ayrılmak konusundaki bilinçli ve temkinli bir kararı veya niyeti de ifade etmektedir (Alexander vd, 1994; 518; Bartlett,1999: 70). Bir çalışanın işten ayrılma niyetinin işten ayrılma davranışına dönüşmesi belirli bir sureci takip etmekte ve bu süreç dış unsurlar (işsizlik oranı, alternatif iş olanakları gibi), örgütsel unsurlar (yönetim tarzı, ücret, ödüllendirme gibi) ve kişisel unsurlardan (kişilik, yaş, aile gibi) oluşmaktadır (Hom vd., 1992: 905; Cotton ve Tuttle, 1986: 63-64; Şahin, 2011:277; Weisberg, 1994:4).

İşgörenin psikolojik sözleşmeye ilişkin yükümlülüklerin yerine getirilmediği yönündeki algıSı örgüt açısından istenmeyen sonuçlar doğurabilmektedir (Cihangiroğlu ve Şahin, 2010: 13). Bu sonuçlardan biri de işgörenin işten ayrılma niyetinin artması şeklinde olabilmektedir (Singh, 1998: 62). Bu nedenle işten ayrılma niyeti psikolojik sözleşme ile en fazla ilişkilendirilen bir tutum olarak belirtilmektedir (Zao vd., 2007: 650). Yapılan araştırmalarda psikolojik sözleşmenin ihlalinde işgörenlerin örgütte kalma isteklerinin azaldığı görülmektedir (Lee ve Faller, 2005: 832; 


\section{S.ASLAN - S.UYAR}

Robinson, 1996:575; Seçkin, 2011: 24). Bu görüşe dayalı olarak hipotez 5 ve hipotez 6 geliştirilmiştir:

H5. Algllanan psikolojik sözleşme ihlali ile işten ayrlma niyeti pozitif ilişkilidir.

H6. Algılanan psikolojik sözleşme ihlalinin hissettirdikleri ile işten ayrılma niyeti negatif ilişkilidir.

\section{YÖNTEM}

\subsection{Araştırma Modeli}

$\mathrm{Bu}$ çalışmada, psikolojik sözleşmenin ihlali ve psikolojik sözleşme ihlalinin hissettirdikleri ile sağlık çalışanlarındaki örgütsel özdeşleşme, iş tatmini ve işten ayrılma arasındaki ilişki incelenmiştir. Veriler SPSS 10.0 ile değerlendirilmiştir. Geçerliliğini ölçmek amacıyla LISREL VIII programıyla doğrulayıcı faktör analizi (CFA) uygulanmıştır. Ayrıca tanımlayıcı istatistikler, korelasyon ve regresyon analizi de yapılmıştır. Araştırma modeli Şekil 1' de gösterilmiştir.

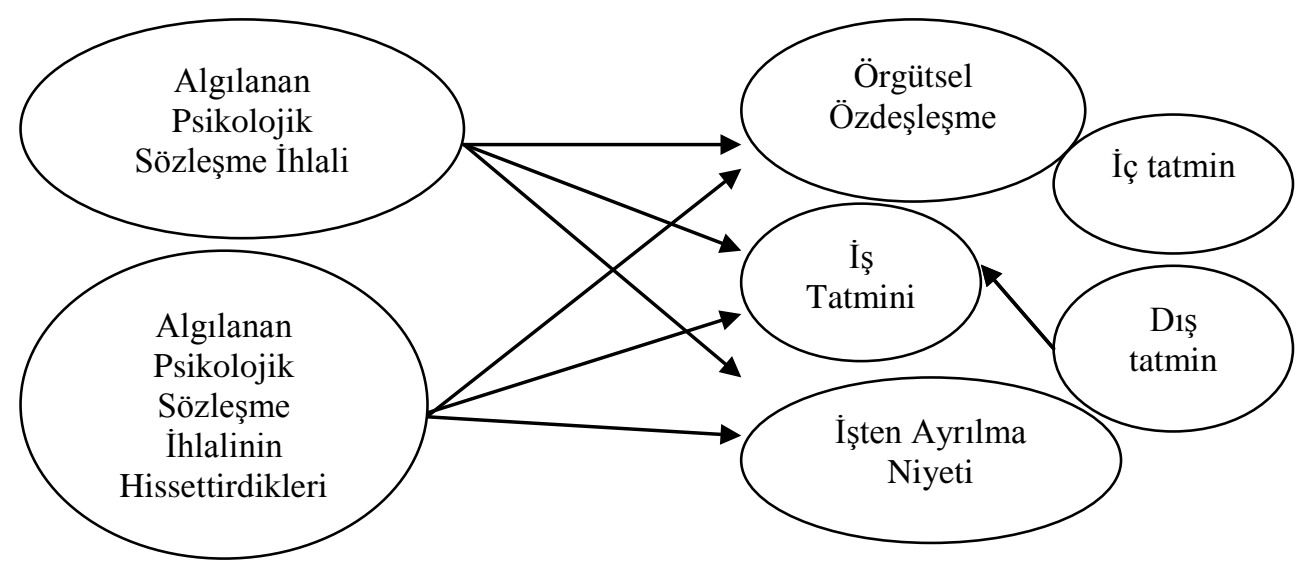

Şekil 1. Araştırma Modeli 


\subsection{Katılımcilar}

Araştırma, İç Anadolu ve Akdeniz bölgesinden 4 ildeki 4 hastaneden rastgele örneklem seçilerek 300 sağlık çalışanı ile gerçekleştirilmiştir. Hastane büyüklüklerine göre "tabakalı örnekleme” yöntemiyle 150'şer ve 50 'şer olmak üzere "rastgele örnekleme" metodu kullanılarak katılımcılara ulaşılmıştır. Araştırmaya katılanların büyük çoğunluğu, evli (\%53.7), ön lisans (\%28.7) ve lisans (\%27.7) düzeyinde öğrenim görmüş, hemşire (\%32) ve idari personel (\%20.3), kadın (\%58), büyük çoğunluğu 18-27 yaş aralığında (\%52.7) ve 28-37 yaş grubunda (\%32.3) çalışandan oluşmaktadır.

\section{3. Ölçekler}

Araştırmada algılanan psikolojik sözleşmeyi ihlal, psikolojik sözleşmeyi ihlalin hissettirdikleri, örgütsel özdeşleşme, iş tatmini ve işten ayrılma niyeti ölçeği olmak üzere dört ölçekten yararlanılmıştır.

\subsubsection{Algılanan Psikolojik Sözleşme İhlali (Perceived Psychological}

ContractBreach) Ölçeği: Robinson ve Morrison’un (2000) çalışmasından alınmıştır. Ölçekte toplam 5 soru bulunmaktadır, üç soru ters kodludur. Ölçek soruları alandan 8 akademik personel tarafından çeviri-geri çeviri yöntemiyle İngilizce'den Türkçe’ye çevrilmiştir. 5’li Likert ile “hiç katılmıyorum $=1$ " ve "kesinlikle kat1liyorum=5" şeklinde derecelendirilmiştir. Robinson ve Morrison'un (2000) çalışmasında ölçeğin Cronbach Alpha katsayısı .92 olarak yüksek düzeyde bulunmuştur. $\mathrm{Bu}$ çalışmada ölçeğin doğrulayıcı faktör analiziyle (Confirmatory Factor Analysis) yapısal geçerliği, AVE (The Average Variance Extracted) katsayısıyla yakınsak geçerliliğine, CR (Construct Reliability) katsayısıyla Cronbach Alpha katsayısıyla yapı güvenilirliğine bakılmıştır.

\subsubsection{Algılanan Psikolojik Sözleşme İhlalinin Hissettirdikleri (Feelings of Psychological Contract Violation) Ölçeği: Robinson ve}




\section{Ş.ASLAN - S.UYAR}

Morrison'un (2000) çalışmasından alınmıştır. Ölçekte toplam 4 soru bulunmaktadır. Ölçek soruları alandan 8 akademik personel tarafından çeviri-geri çeviri yöntemiyle İngilizce'den Türkçe’ye çevrilmiştir. 5’liLikert (hiç katılmıyorum=1 ve kesinlikle katılıyorum=5) şeklinde derecelendirilmiştir. Robinson ve Morrison’un (2000) çalışmasında ölçeğin Cronbach Alpha katsayısı .92 yüksek düzeyde bulunmuştur. Bu çalışmada ölçeğin doğrulayıcı faktör analiziyle yapısal geçerliği, AVE katsayısıyla yakınsak geçerliliğine, CR katsayısıyla Cronbach Alpha katsayısıyla yapı güvenilirliğine bakılmıştır.

\subsection{3. Örgütsel Özdeşleşme (Organizational Identification) Ölçeği:}

Ölçeğin kaynağını 8 soruluk Mael'in (1986) çalışması oluşturmaktadır. Ölçek soruları alandan 8 akademik personel tarafından çeviri-geri çeviri yöntemiyle İngilizce'den Türkçe'ye çevrilmiştir. Mael’in (1988), çalışmasında ölçeğin Cronbach Alpha katsayısı.79olarak bulunmuştur. Çalışmada kullanılan ölçek, Mael ve Ashforth (1992) çalışmasından alınmış, 6 soruluk bir ölçektir.Mael ve Ashforth (1992) çalışmasında ölçeğin Cronbach alfa katsayısı.787; olarak bulunmuştur. 5’li Likert ile (5=Kesinlikle Katılmiyorum, 5= Kesinlikle Katılıyorum) derecelendirilmiştir. $\mathrm{Bu}$ çalışmada ölçeğin doğrulayıcı faktör analiziyle yapısal geçerliği, AVE katsayısıyla yakınsak geçerliliğine, CR katsayısıyla Cronbach Alpha katsayısıyla yapı güvenilirliğine bakılmıştır.

\subsection{4. İş Tatmini (Job Satisfaction, External-Internal) Ölçeği:}

Minnesota İş Tatmini ölçeği (Minnesota Satisfaction Questionnaire), Weiss ve Ark. (1967) tarafından geliştirilmiştir. Ölçeğin iki alt boyutu bulunmaktadır. İçtatmin: 1, 2, 3, 4, 7, 8, 9, 10, 11, 15, 16, 20 maddelerden oluşmuştur. Başarı, tanınma veya takdir edilme, işin kendisi, işin sorumluluğu, yükselme ve terfie bağlı görev değişikliği gibi işin iç niteliğine 
Dokuz Eylül Üniversitesi İktisadi ve İdari Bilimler Fakültesi Dergisi Cilt:33, Sayl:1, Yll:2018, ss. 1-38 ilişkin tatminkarlıkla ilgili öğelerden oluşmaktadır. Dış tatmin: 5, 6, 12, 13, $14,17,18$ ve 19 maddelerinden oluşmuştur. İşletme politikası ve yönetimi, denetim şekli, yönetici, çalışma ve astlarla ilişkiler, çalışma koşulları, ücret gibi işin çevresine ait öğelerden oluşmaktadır. Ölçek, ilk olarak Baycan (1985) tarafından Türkçe'ye çevrilmiş, geçerlik ve güvenirlik çalışmaları yapılarak sağlıkta çalışanların iş tatmin düzeylerini saptamak amacıyla kullanılmıştır. Baycan yapılan güvenilirlik analizi sonucunda Cronbach Alpha katsayısını.77 olarak bulmuştur. Bu çalışmada ölçeğin doğrulayıcı faktör analiziyle yapısal geçerliği, AVE katsayısıyla yakınsak geçerliliğine, CR katsayısıyla Cronbach Alfa katsayısıyla yapı güvenilirliğine bakılmıştır.

3.3.5. İşten Ayrılma Niyeti (Intention to Quit) Ölçeği: Wayne, Shore ve Lidern'in (1997)çalışmasından alınan 5 soruluk bir ölçektir. 5’li Likert ile $(1=$ Kesinlikle Katılmiyorum, $7=$ Kesinlikle Kat1liyorum $)$ derecelendirilmiştir. Ölçeğin Cronbach Alpha katsayısı.89 olarak bulunmuştur. Ölçekte 5. Soru ters kodlanmıştır. Bu çalışmada ölçeğin doğrulayıcı faktör analiziyle yapısal geçerliği, AVE katsayısıyla yakınsak geçerliliğine, CR katsayısıyla ve Cronbach Alpha katsayısıyla yapı güvenilirliğine bakılmıştır.

\subsection{Bulgular}

Araştırmada yer alan ölçeklerin geçerlikleri ve güvenilirlikleri araştırılmıştır. Lisrel'de yapılacak analizlere ek olarak geçerlik ve güvenilirlik katsayılarının sunulması gerekir. Güvenilirlik (reliability) için madde güvenilirliği (item reliability), yap1 güvenilirliği (construct reliability) önerilmektedir. Madde güvenilirliği, her soru için faktör yüklerinin kareleri yoluyla hesaplanır; sonucun .50 'den yüksek olması beklenir ve faktör yükü .70'in üzerindeki sorularda .50 ve yukarı sonucuna ulaşılabilir (Fornell ve Larcker, 1981). Yap1 güvenilirliği (construct reliability:CR) katsayısının .70'den yukarıda olması güvenilirliğin 


\section{Ş.ASLAN - S.UYAR}

göstergesi kabul edilir (Peterson, 1994). Yapı güvenilirliği (CR), Cronbach Alpha (iç tutarlılık: internal consistency of measures) yerine bakılan iç tutarlılık ölçümüdür (Portney ve Watkins, 1993).

Doğrulayıcı faktör analizi (Confirmatory Factor Analysis), yapısal geçerliği araştırmada kullanılmaktadır (Baydur ve Eser, 2006). Yapı geçerliliği (Construct validity) ise "yakınsak geçerlilik" (convergent validity) ve "ayırt edici geçerlilik" (discriminant validity) olmak üzere iki şekilde bakılmaktadır (Fornell and Larcker, 1981). Yakınsak geçerlilik (AVE: The Average Variance Extracted) katsayısının .50'nin üzerinde olması istenir (Bagozzive Yi, 1988). Son olarak doğrulayıcı faktör analizinde $t$ değerinin de anlamlı olması gerekir (Hui, 2003). Analizler sonucunda uyum iyiliği indeksleri $\chi 2 / \mathrm{df}$ oranın $<5$ olması kabul edilebilir durumunda olduğunu; <2'den olması iyi uyum düzeyinde olduğunu göstermektedir (Li, Ragu-Nathan ve Ragu-Nathan, 2005:629). RMSEA değerinin0 ve 0.05 'den küçük veya eşit olması model veri uyumunun mükemmel olduğunu göstermektedir (Yücenur vd., 2011: 164; SchermellehEngelvd., 2003: 36). GFI ve NFI'nin 0.90'a eşit veya üzerinde olması, CFI ve NNFI'nın 95'e eşit veya üzerinde olması ve AGFI'nin .85'e eşit ve üzerinde olması modelin kabul edilebilir düzeyde olduğunu göstermektedir (Hu ve Bentler, 1999: 4; Steiger, 1990:177; Schermelleh-Engel vd., 2003: 52). Son olarak ölçek sorularının ortalamaları ve standart sapmaları hesaplanmıştır. Her maddenin genel ölçek puanıyla ilişkisine madde-toplam korelâsyonuna bakılmıştır. Buna göre korelasyon katsayılarının negatif olmaması ve >0.25 olması gerekmektedir (Altunış1k vd., 2012: 228). 
Dokuz Eylül Üniversitesi İktisadi ve İdari Bilimler Fakültesi Dergisi Cilt:33, Sayl:1, Yıl:2018, ss. 1-38

Tablo 1. Doğrulayıcı Faktör Analizi Sonucu: Algılanan Psikolojik Sözleşme İhlali

\begin{tabular}{|c|c|c|c|c|c|c|c|c|c|}
\hline Dimension & (CFA) & (CFA)* & $t$-value & $\begin{array}{c}\text { Item } \\
\text { Reliability }\end{array}$ & CR & AVE & Mean & Std. Dev. & $\begin{array}{l}\text { Item-Total } \\
\text { Corelation }\end{array}$ \\
\hline $\begin{array}{c}\text { Perceived } \\
\text { Psychological } \\
\text { Contract } \\
\end{array}$ & & & & & .90 & .76 & & & \\
\hline 1 & .83 & .83 & 17.22 & .68 & & & 3.04 & 1.11 & $.909 * *$ \\
\hline 2 & .94 & .94 & 20.76 & .88 & & & 3.08 & 1.10 & $.940^{* *}$ \\
\hline 3 & .85 & .85 & 17.8 & .72 & & & 2.97 & 1.02 & $.907^{* *}$ \\
\hline 4 & $-.08^{*}$ & & & & & & & & \\
\hline 5 & $-.01 *$ & & & & & & & & \\
\hline
\end{tabular}

Note: Standardized item loadings reported for CFA. $\mathrm{p}<.001$ for all loadings. **Correlation is significant at the 0.01 level (2-tailed).

*Negatif yönde olan veya faktör yükü .70’in altında olup ölçekten çıkartılan soru **Boyutta tek kaldığı için çıkartılan soru

${ }^{\mathrm{a}}$ Düzeltme indeksi veren, ölçekten çıkartılan soru

Goodness-of-Fit Statistics: $\chi 2 / \mathrm{df}=56.22 / 5=11.25$, NFI $=.91$, NNFI=.83, CFI=.92, AGFI=.79, GFI=.93, RMSEA=.18,

(Goodness-of-Fit Statistics: $\chi 2 / \mathrm{df}=2.54, \mathrm{NFI}=.94, \mathrm{NNFI}=.98, \mathrm{CFI}=.99, \mathrm{AGFI}=.91, \mathrm{GFI}=.99, \mathrm{RMSEA}=.08$ ).

CR: Yapı GeçerliliğiConstruct reliablity).AVE $<.50$

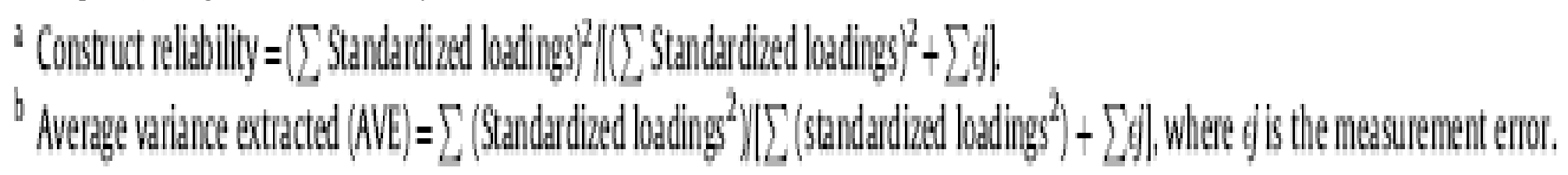


Ş.ASLAN - S.UYAR

Tablo 2. Uyum İyiliği İndeksleri: Algılanan Psikolojik Sözleşme İhlali

\begin{tabular}{|c|c|c|c|c|c|c|c|}
\hline $\begin{array}{c}\text { Uyum İyiliği } \\
\text { İndeksleri }\end{array}$ & $\chi \mathbf{2} / \mathbf{d f}$ & NFI & NNFI & CFI & AGFI & GFI & RMSEA \\
\hline Model I & $56.22 / 5=11.25$ & .91 & .83 & .92 & .79 & .93 & .18 \\
\hline Model II & $5.02 / 2=2.54$ & .94 & .98 & .99 & .91 & .99 & .08 \\
\hline
\end{tabular}

Tablo 2'de görüldüğü gibi, algılanan psikolojik sözleşme ihlali ölçeğinin başlangıç versiyonunda uyum iyiliği göstergesi (Goodness-of-Fit Statistics: $\chi 2 / \mathrm{df}=56.22 / 5=11.25, \mathrm{NFI}=.91, \mathrm{NNFI}=.83, \mathrm{CFI}=.92, \mathrm{AGFI}=.79, \mathrm{GFI}=.93$, RMSEA=.18) olarak iyi değerlere ulaşılamamıştır. Hem negatif hem .40'ın altında ve hem de düzeltme indeksi gösteren 4. ve 5. sorular ölçekten çıkartılarak ölçek yeniden doğrulayıcı faktör analizine tabi tutulmuş ve iyi uyum değerlerine ulaşılmıştır (Goodness-of-Fit Statistics: $\chi 2 / \mathrm{df}=2.54$, NFI=.94, NNFI=.98, CFI=.99, AGFI=.91， GFI=.99， RMSEA=.08). Dolayısıyla 3 soruluk Türkiye'de geçerli ve güvenilir (CR: .90, AVE: .76 ve Cronbach Alpha: .907) yeni bir algılanan psikolojik sözleşme ihlali ölçeği elde edilmiştir.

Algılanan psikolojik sözleşme ihlalinin hissettirdikleri ölçeğinin başlangıç versiyonunda uyum iyiliği göstergesi (Goodness-of-Fit Statistics: $\chi 2 / \mathrm{df}=30.92 / 2=15.46, \mathrm{NFI}=.95, \mathrm{NNFI}=.87, \mathrm{CFI}=.96, \mathrm{AGFI}=.75, \mathrm{GFI}=.95$, RMSEA=.02) olarak iyi değerlere ulaşılamamıştır. Düzeltme indeksi gösteren 4. soru ölçekten çıkartılarak ölçek yeniden doğrulayıcı faktör analizine tabi tutulmuş ve iyi uyum değerlerine ulaşılmıştır (Goodness-ofFit Statistics: $\chi 2 / \mathrm{df}=7.12 / 2=3.56, \quad \mathrm{NFI}=.95, \quad \mathrm{NNFI}=.97, \quad \mathrm{CFI}=.96$, AGFI=.90, GFI=.96, RMSEA=.02). Dolayısıyla 3soruluk Türkiye'de geçerli ve güvenilir (CR: .86, AVE: .68 ve Cronbach Alpha: .861) yeni bir algılanan psikolojik sözleşme ihlalinin hissettirdikleri ölçeği elde edilmiştir. 
Dokuz Eylül Üniversitesi İktisadi ve İdari Bilimler Fakültesi Dergisi Cilt:33, Sayı:1, Yıl:2018, ss. 1-38

Tablo 3. Doğrulayıcı Faktör Analizi Sonucu: Algılanan Psikolojik Sözleşme ihlalinin Hissettirdikleri

\begin{tabular}{|c|c|c|c|c|c|c|c|c|c|}
\hline Dimension & (CFA) & (CFA)* & $t$-value & $\begin{array}{c}\text { Item } \\
\text { Reliability }\end{array}$ & CR & AVE & Mean & Std.Dev. & $\begin{array}{l}\text { Item-Total } \\
\text { Corelation }\end{array}$ \\
\hline $\begin{array}{l}\text { Feelings of Psychological } \\
\text { Contract violation* }\end{array}$ & & & & & .86 & .68 & & & \\
\hline 1 & .83 & .82 & 16.14 & .67 & & & 2.10 & 1.09 & $.887 * *$ \\
\hline 2 & .86 & .91 & 18.55 & .82 & & & 2.07 & 1.08 & $.911 * *$ \\
\hline 3 & .79 & .73 & 13.98 & .53 & & & 2.20 & 1.09 & $.856 * *$ \\
\hline 4 & $.76^{a}$ & & & & & & & & \\
\hline
\end{tabular}

Note: Standardized item loadings reported for CFA. $\mathrm{p}<.001$ for all loadings. ${ }^{* *}$ Correlation is significant at the 0.01 level (2-tailed).

*Negatif yönde olan veya faktör yükü .70’in altında olup ölçekten çıkartılan soru **Boyutta tek kaldığ için çıkartılan soru

${ }^{a}$ Düzeltme indeksi veren, ölçekten çıkartılan soru

Goodness-of-Fit Statistics: $\chi 2 / \mathrm{df}=30.92 / 2=15.46$, NFI= .95, NNFI=.87, CFI=.96, AGFI=.75, GFI=.95, RMSEA=.02,

(Goodness-of-Fit Statistics: $\chi 2 / \mathrm{df}=7.12 / 2=3.56, \mathrm{NFI}=.95, \mathrm{NNFI}=.97, \mathrm{CFI}=.96, \mathrm{AGFI}=.90, \mathrm{GFI}=.96, \mathrm{RMSEA}=.02$ )

Tablo 4. Uyum İyiliği İndeksleri: Algılanan Psikolojik Sözleşme İhlalinin Hissettirdikleri

\begin{tabular}{|c|c|c|c|c|c|c|c|}
\hline Uyum İyiliği İndeksleri & $\chi \mathbf{2} / \mathbf{d f}$ & NFI & NNFI & CFI & AGFI & GFI & RMSEA \\
\hline Model I & $30.92 / 2=15.46$ & .95 & .87 & .96 & .75 & .95 & .02 \\
\hline Model II & $7.12 / 2=3.56$ & .95 & .97 & .96 & .90 & .96 & .02 \\
\hline
\end{tabular}


Ş.ASLAN - S.UYAR

Örgütsel özdeşleşme ölçeğinin başlangıç versiyonunda uyum iyiliği göstergesi (Goodness-of-Fit Statistics: $\chi 2 / \mathrm{df}=64.89 / 9=7.21, \mathrm{NFI}=.87$, $\mathrm{NNFI}=.81, \mathrm{CFI}=.89$, $\mathrm{AGFI}=.84, \mathrm{GFI}=.93$, $\mathrm{RMSEA}=.14$ ) olarak iyi değerlere ulaşılamamıştır. Düzeltme indeksi gösteren 2. ve 3. sorular ölçekten çıkartılarak ölçek yeniden doğrulayıcı faktör analizine tabi tutulmuş ve iyi uyum değerlerine ulaşılmıştır (Goodness-of-Fit Statistics: $\chi^{2 / \mathrm{df}}$ $=2.75 / 2=1.37, \mathrm{NFI}=.99, \mathrm{NNFI}=.99, \mathrm{CFI}=1.00, \mathrm{AGFI}=.98, \mathrm{GFI}=1.00$, RMSEA=.03). Ölçeğin CR: .76, AVE: .52 ve Cronbach Alpha: .749 olmas1 nedeniyle Türkiye'de geçerli ve güvenilir 3 soruluk yeni bir Örgütsel Özdeşleşme ölçeği elde edilmiştir. 
Dokuz Eylül Üniversitesi İktisadi ve İdari Bilimler Fakültesi Dergisi Cilt:33, Sayı:1, Yll:2018, ss. 1-38

Tablo 5. Doğrulayıcı Faktör Analizi Sonucu: Örgütsel Özdeşleşme

\begin{tabular}{|c|c|c|c|c|c|c|c|c|c|}
\hline Dimension & (CFA) & (CFA)* & $t$-value & $\begin{array}{c}\text { Item } \\
\text { Reliability }\end{array}$ & CR & AVE & Mean & Std.Dev. & $\begin{array}{l}\text { Item-Total } \\
\text { Corelation }\end{array}$ \\
\hline $\begin{array}{l}\text { Organizational } \\
\text { Identificiation * }\end{array}$ & & & & & .76 & .52 & & & \\
\hline 1 & $.53^{a}$ & & & & & & & & \\
\hline 2 & $.57^{a}$ & & & & & & & & \\
\hline 3 & $.59^{a}$ & & & & & & & & \\
\hline 4 & .74 & .68 & 10.88 & .4624 & & & 3.31 & 1.15 & $.809 * *$ \\
\hline 5 & .75 & .89 & 13.67 & .7921 & & & 3.23 & 1.19 & $.864^{* *}$ \\
\hline 6 & .61 & .57 & 9.39 & .3249 & & & 3.14 & 1.16 & $.774^{* *}$ \\
\hline
\end{tabular}

Note: Standardized item loadings reported for CFA. $\mathrm{p}<.001$ for all loadings.**Correlation is significant at the 0.01 level (2-tailed).

*Negatif yönde olan veya faktör yükü .70’in altında olup ölçekten çıkartılan soru **Boyutta tek kaldığı için çıkartılan soru

${ }^{\mathrm{a}}$ Düzeltme indeksi veren, ölçekten çıkartılan soru

Goodness-of-Fit Statistics: $\chi 2 / \mathrm{df}=64.89 / 9=7.21$, NFI= .87, NNFI=.81, CFI=.89, AGFI=.84, GFI=.93, RMSEA=.14,

Goodness-of-Fit Statistics: $\chi 2 / \mathrm{df}=2.75 / 2=1.37, \mathrm{NFI}=.99, \mathrm{NNFI}=.99, \mathrm{CFI}=1.00, \mathrm{AGFI}=.98, \mathrm{GFI}=1.00, \mathrm{RMSEA}=.03$.

Tablo 6. Uyum İyiliği İndeksleri: Örgütsel Özdeşleşme

\begin{tabular}{|c|c|c|c|c|c|c|c|}
\hline Uyum İyiliği İndeksleri & $\chi 2 / \mathbf{d f}$ & NFI & NNFI & CFI & AGFI & GFI & RMSEA \\
\hline Model I & $64.89 / 9=7.21$ & .87 & .81 & .89 & .84 & .93 & .14 \\
\hline Model II & $2.75 / 2=1.37$ & .99 & .99 & 1.00 & .98 & 1.00 & .03 \\
\hline
\end{tabular}




\section{S.ASLAN - S.UYAR}

Tablo 7. Doğrulayıcı Faktör Analizi Sonucu: İ̧̧ Tatmini

\begin{tabular}{|c|c|c|c|c|c|c|c|c|c|c|c|}
\hline Dimension & $\mathbf{( C F A )}$ & $\mathbf{( C F A )}$ & $\mathbf{( C F A ) * *}$ & $\mathbf{( C F A ) * * *}$ & $\begin{array}{c}\boldsymbol{t} \text { - } \\
\text { value }\end{array}$ & $\begin{array}{c}\text { Item } \\
\text { Reliability }\end{array}$ & CR & AVE & Mean & Std.Dev. & $\begin{array}{c}\text { Item-Total } \\
\text { Corelation }\end{array}$ \\
\hline $\begin{array}{c}\text { Job } \\
\text { Satisfaction* }\end{array}$ & .776 & & & & & & .82 & .48 & & & \\
\hline Internal & .688 & & & & & & .65 & .47 & 2.33 & .909 & \\
\hline $\mathbf{1}$ & $.58^{*}$ & & & & & & & & & & \\
\hline $\mathbf{2}$ & $.63^{*}$ & & & & & & & & & & \\
\hline $\mathbf{3}$ & $.64^{*}$ & & & & & & & & & & \\
\hline $\mathbf{4}$ & .64 & .58 & $.58^{*}$ & & & & & & & & \\
\hline $\mathbf{7}$ & $.44^{*}$ & & & & & & & & & & \\
\hline $\mathbf{8}$ & .62 & .52 & .71 & .71 & 10.14 & .5041 & & & 2.22 & 1.070 & \\
\hline $\mathbf{9}$ & $.61^{*}$ & & & & & & & & & & $.862^{* *}$ \\
\hline $\mathbf{1 0}$ & $.59^{*}$ & & & & & & & & & & \\
\hline $\mathbf{1 1}$ & .64 & .60 & .67 & .67 & 9.68 & .4489 & & & 2.43 & 1.047 & $.856^{* *}$ \\
\hline $\mathbf{1 5}$ & .69 & $.75^{a}$ & & & & & & & & & \\
\hline $\mathbf{1 6}$ & .66 & $.74^{a}$ & & & & & & & & & \\
\hline $\mathbf{2 0}$ & $.61^{*}$ & & & & & & & & & & \\
\hline External & .741 & & & & & & .74 & .49 & & & \\
\hline $\mathbf{5}$ & .75 & $.81^{a}$ & & & & & & & & & \\
\hline $\mathbf{6}$ & .72 & $.79^{a}$ & & & & & & & & & \\
\hline $\mathbf{1 2}$ & $.60^{*}$ & & & & & & & & & & \\
\hline $\mathbf{1 3}$ & $.52^{*}$ & & & & & & & & & & \\
\hline
\end{tabular}


Dokuz Eylül Üniversitesi İktisadi ve İdari Bilimler Fakültesi Dergisi

\begin{tabular}{|c|c|c|c|c|c|c|c|c|c|}
\hline & & & & & & & \multicolumn{3}{|c|}{ Cilt:33, Sayl:1, Yul:2018, ss. 1-38 } \\
\hline 14 & $.63 *$ & & & & & & & & \\
\hline 17 & .71 & .68 & .65 & .64 & 10.77 & .4225 & 2.66 & 1.065 & $.793^{* *}$ \\
\hline
\end{tabular}

Tablo 7. Doğrulayıcı Faktör Analizi Sonucu: İş Tatmini (Devamı)

\begin{tabular}{|c|c|c|c|c|c|c|c|c|c|c|c|}
\hline Dimension & (CFA) & (CFA)* & $(\mathrm{CFA})^{* *}$ & $(\mathrm{CFA}) * * *$ & $t$-value & $\begin{array}{c}\text { Item } \\
\text { Reliability }\end{array}$ & CR & AVE & Mean & Std.Dev. & $\begin{array}{l}\text { Item-Total } \\
\text { Corelation }\end{array}$ \\
\hline 18 & .61 & .65 & .75 & .75 & 12.84 & .5625 & & & 2.42 & 1.059 & $.827 * *$ \\
\hline 19 & .64 & .61 & .71 & .71 & 11.95 & .5041 & & & 2.35 & 1.103 & $.816^{* *}$ \\
\hline
\end{tabular}

Note: Standardized item loadings reported for CFA. $\mathrm{p}<.001$ for all loadings. ${ }^{* *}$ Correlation is significant at the 0.01 level (2-tailed).

*Negatif yönde olan veya faktör yükü .70’in altında olup ölçekten çıkartılan soru **Boyutta tek kaldığı için çıkartılan soru

${ }^{\mathrm{a}}$ Düzeltme indeksi veren, ölçekten çıkartılan soru

Goodness-of-Fit Statistics: $\chi 2 / \mathrm{df}=1106.64 / 169=6.54, \mathrm{NFI}=.67, \mathrm{NNFI}=.67, \mathrm{CFI}=.71, \mathrm{AGFI}=.66, \mathrm{GFI}=.73, \mathrm{RMSEA}=.13$

Goodness-of-Fit Statistics: $\chi 2 / \mathrm{df}=298.58 / 34=8.78, \mathrm{NFI}=.82, \mathrm{NNFI}=.78, \mathrm{CFI}=.84, \mathrm{AGFI}=.73, \mathrm{GFI}=.83, \mathrm{RMSEA}=.16$.

Goodness-of-Fit Statistics: $\chi 2 / \mathrm{df}=4.41 / 8=0.55, \mathrm{NFI}=.99, \mathrm{NNFI}=1.00, \mathrm{CFI}=1.00, \mathrm{AGFI}=.99, \mathrm{GFI}=1.00, \mathrm{RMSEA}=.00$.

Goodness-of-Fit Statistics: $\chi 2 / \mathrm{df}=1.45 / 4=0.36, \mathrm{NFI}=1.00, \mathrm{NNFI}=1.00, \mathrm{CFI}=1.00, \mathrm{AGFI}=.99, \mathrm{GFI}=1.00, \mathrm{RMSEA}=.00$

Tablo 8. Uyum İyiliği İndeksleri: İș Tatmini

\begin{tabular}{|c|c|c|c|c|c|c|c|}
\hline Uyum İyiliği İndeksleri & $\chi \mathbf{2} / \mathbf{d f}$ & NFI & NNFI & CFI & AGFI & GFI & RMSEA \\
\hline Model I & $1106.64 / 169=6.54$ & .67 & .67 & .71 & .66 & .73 & .13 \\
\hline Model II & $298.58 / 34=8.78$ & .82 & .78 & .84 & .73 & .83 & .16 \\
\hline Model III & $4.41 / 8=0.55$ & .99 & 1.00 & 1.00 & .99 & 1.00 & 00 \\
\hline
\end{tabular}




\section{S.ASLAN - S.UYAR}

İş tatmini ölçeğinin başlangıç versiyonunda uyum iyiliği göstergesi (Goodness-of-Fit Statistics: $\chi 2 / \mathrm{df}=1106.64 / 169=6.54, \mathrm{NFI}=.67$, NNFI $=.67$, CFI $=.71, \quad$ AGFI $=.66, \quad$ GFI $=.73, \quad$ RMSEA=.13) olarak iyi değerlere ulaşılamamıştır. Düzeltme indeksi gösteren ve faktör yükü düşük düzeyde olan 1.,2.,3.,7.,9.,10.,12., 13., 14., ve 20. sorular ölçekten çıkartılarak doğrulayıcı faktör analizine tabi tutulmuş ve iyi uyum değerlerine ulaşılmamışırı (Goodness-of-Fit Statistics: $\chi 2 / \mathrm{df}=298.58 / 34=8.78$, NFI= .82, NNFI $=.78$, CFI $=.84$, AGFI $=.73$, GFI $=.83$, RMSEA=.16.). Düzeltme indeksi gösteren 5., 6., 15. ve 16. sorular ölçekten çıkartılarak ölçek yeniden doğrulayıcı faktör analizine tabi tutulmuş ve iyi uyum değerlerine ulaşı1lamamıştır (Goodness-of-Fit Statistics: $\chi 2 / \mathrm{df}=4.41 / 8=0.55, \mathrm{NFI}=.99$, NNFI=1.00, CFI=1.00, AGFI=.99, GFI=1.00, RMSEA=.00). .58 faktör yüküne sahip soru ölçekten çıkartılarak yeniden faktör analizine tabi tutulmuştur. CR: .82, AVE: .48 katsayıları düşük olmakla birlikte Ölçeğin Cronbach Alpha katsayısı iç tatmin boyutunda .645, dış tatmin boyutu .741 ve toplam iş tatmini ölçeği .759 olması nedeniyle düşük ancak kabul edilebilir düzeyde Türkiye'de geçerli ve güvenilir 5 soruluk 2 boyutlu yeni bir sağlık çalışanları için iş tatmini ölçeğine ulaşılmıştır (Goodness-of-Fit Statistics: $\quad \chi 2 / \mathrm{df}=1.45 / 4=0.36, \quad \mathrm{NFI}=1.00, \quad \mathrm{NNFI}=1.00, \quad \mathrm{CFI}=1.00$, AGFI=.99, GFI=1.00, RMSEA=.00). Son ulaşılan ölçeğin bir boyutunda 2 sorudan oluştuğu görülmekte literatürde genellikle 3 sorudan oluşması önerilmekle birlikte önemli ölçeklerde boyutları 2 sorudan oluşan öleçklerin de geçerli ve güvenilir olarak kabul edilebildiği görülmektedir (Hoyt ve Blascovich, 2003). 
Dokuz Eylül Üniversitesi İktisadi ve İdari Bilimler Fakültesi Dergisi Cilt:33, Sayı:1, Yıl:2018, ss. 1-38

Tablo 9. Doğrulayıcı Faktör Analizi Sonucu: İşten Ayrılma Niyeti

\begin{tabular}{|c|c|c|c|c|c|c|c|c|c|c|}
\hline Dimension & (CFA) & (CFA)* & $(\mathrm{CFA})^{* *}$ & $\begin{array}{c}t- \\
\text { value }\end{array}$ & $\begin{array}{c}\text { Item } \\
\text { Reliability }\end{array}$ & CR & AVE & Mean & Std.Dev. & $\begin{array}{l}\text { Item-Total } \\
\text { Corelation }\end{array}$ \\
\hline Intention to Quit * & & & & & & .92 & .90 & & & \\
\hline 1 & .86 & .87 & .82 & 17.13 & .67 & & & 2.21 & 1.085 & $.903 * *$ \\
\hline 2 & .85 & $.85^{a}$ & & & & & & & & \\
\hline 3 & .90 & .90 & .91 & 19.75 & .82 & & & 2.28 & 1.169 & $.937 * *$ \\
\hline 4 & .91 & .91 & .94 & 21.17 & .88 & & & 2.29 & 1.124 & $.946 * *$ \\
\hline 5 (reverse coded) & $.21 *$ & & & & & & & & & \\
\hline
\end{tabular}

Note: Standardized item loadings reported for CFA. $\mathrm{p}<.001$ for all loadings. ${ }^{* *}$ Correlation is significant at the 0.01 level (2-tailed).

*Negatif yönde olan veya faktör yükü .70’in altında olup ölçekten çıkartılan soru **Boyutta tek kaldığı için çıkartılan soru

${ }^{a}$ Düzeltme indeksi veren, ölçekten çıkartılan soru

Goodness-of-Fit Statistics: $\chi 2 / \mathrm{df}=54.58 / 5=10.91$, NFI $=.95$, NNFI=.91, CFI=.96, AGFI=.80, GFI=.93, RMSEA=.18.2Goodness-of-Fit Statistics: $\chi 2 / \mathrm{df}=1.15 / 2=.57, \mathrm{NFI}=1.00, \mathrm{NNFI}=1.00, \mathrm{CFI}=1.00, \mathrm{AGFI}=.99, \mathrm{GFI}=1.00, \mathrm{RMSEA}=.00$.

Tablo 10. Uyum İyiliği İndeksleri: İșten Ayrılma Niyet

\begin{tabular}{|l|l|l|l|l|l|l|l|}
\hline Uyum İyiliği İndeksleri & $\chi \mathbf{2} / \mathbf{d f}$ & NFI & NNFI & CFI & AGFI & GFI & RMSEA \\
\hline Model I & $54.58 / 5=10.91$ & .95 & .91 & .96 & .80 & .93 & .18 \\
\hline Model II & $1.15 / 2=.57$ & 1.00 & 1.00 & 1.00 & .99 & 1.00 & .00 \\
\hline
\end{tabular}




\section{S.ASLAN - S.UYAR}

İşten ayrılma niyeti ölçeğinin başlangıç versiyonunda başlangıç uyum iyiliği göstergesi iyi uyum değerlerine ulaşılamamıştır. 5. soru .21 faktör yüküne sahip bulunmuş ve ölçekten çıkartılarak yeniden analize tabi tutulmuştur. (Goodness-of-Fit Statistics: $\chi 2 / \mathrm{df}=54.58 / 5=10.91$, NFI $=.95$, NNFI=.91, CFI=.96, AGFI=.80, GFI=.93, RMSEA=.18). Düzeltme indeksi gösteren 2. soru ölçekten çıkartılarak ölçek yeniden doğrulayıcı faktör analizine tabi tutulmuş ve iyi uyum değerlerine ulaşılmıştır (Goodness-ofFit Statistics: $\chi 2 / \mathrm{df}=1.15 / 2=.57, \quad \mathrm{NFI}=1.00, \quad \mathrm{NNFI}=1.00, \quad \mathrm{CFI}=1.00$, AGFI=.99, GFI=1.00, RMSEA=.00). Ölçeğin CR: .92, AVE: .90 ve Cronbach Alpha: .920 olması nedeniyle Türkiye'de geçerli ve güvenilir Türkiye'de geçerli ve güvenilir 3 soruluk yeni bir İşten ayrılma ölçeği elde edilmiştir.

Değişkenler arasındaki ilişkiyi belirlemek amacıyla, yol analizinden yararlanılmıştır. Hipotez modeli Şekil 2' de gösterilmiştir.

\subsection{Yapisal Model}

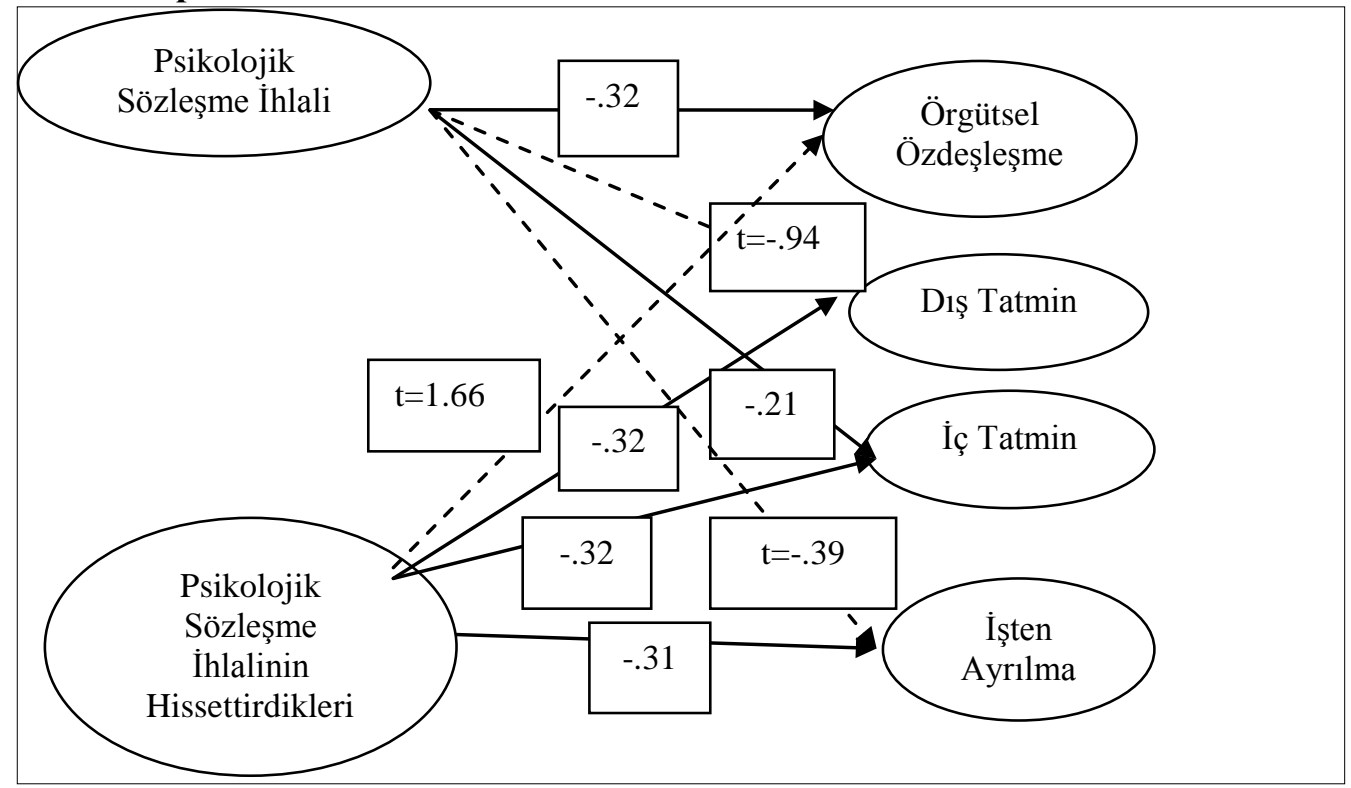

Şekil 2. Araştırma Modeli

..... (geçersiz ilişkiyi gösterir) 
Yol analizinin ilk aşamasında, algılanan psikolojik sözleşme ihlalinden, örgütsel özdeşleşme, iç tatmin, dış tatmin ve işten ayrılma niyeti değişkenlerine yol analizi yapılmıştır. Benzer şekilde algılanan psikolojik sözleşme ihlalinin hissettirdiklerinden örgütsel özdeşleşme, iç tatmin, dış tatmin ve işten ayrılma niyeti değişkenlerine yol analizi yapılmıştır. Algılanan psikolojik sözleşme ihlalinden örgütsel özdeşleşmeye yol (-.32); diş tatmine yol (-.13); iç tatmine yol (-.21); işten ayrılma niyetine yol (-.11) bulunmuştur. Algılanan psikolojik sözleşme ihlalinin hissettirdiklerinden örgütsel özdeşleşmeye yol ( $t=1.66)$ geçersiz bulunurken; dış tatmine yol (.32); iç tatmine yol (-.32); işten ayrılmaya yol (-.31) geçerli bulunmuştur (Goodness-of-Fit Statistics: $\chi 2 / \mathrm{df}=115.07 / 6=19.178$, NNFI=.07, NFI= .63, $\mathrm{CFI}=.63, \mathrm{AGFI}=.60, \mathrm{GFI}=.89$, RMSEA=.25).

Algılanan psikolojik sözleşme ihlalinin hissettirdikleri ile örgütsel özdeşleşme değişkeni arasında ilişki bulunamaması nedeniyle bu yol modelden çıkartılmıştır. Düzeltme indeksi veren modelde, algılanan psikolojik sözleşme ihlali ile iç tatmin ( $\mathrm{t}=-.94)$; algılanan psikolojik sözleşme ile işten ayrılma niyeti ( $t=-$-.39) değişkenleri arasındaki yolun anlamsız çıkması üzerine modelden çıkartılmıştır. Modelde dış tatmin ileiç tatmin (-.38); dış tatmin ile işten ayrılma niyeti (-.31); iç tatmin ile işten ayrılma (-.21) arasında yeni yol tespit edilmiştir ve modele eklenmiştir (Goodness-of-Fit Statistics: $\chi 2 / \mathrm{df}=7.72 / 4=1.93, \quad \mathrm{NNFI}=.95, \quad \mathrm{NFI}=.97$, CFI=.99, AGFI=.96, GFI=.99, RMSEA=.05). Son olarak yapılan düzeltmeden sonra iyi uyum değerlerine ulaşılmıştır (Goodness-of-Fit Statistics: $\chi 2 / \mathrm{df}=8.78 / 6=1.46, \mathrm{NNFI}=.97, \mathrm{NFI}=.97, \mathrm{CFI}=.99$, AGFI=.97, GFI=.99, RMSEA=.04). Sonuç modeli Şekil 3'de gösterilmiştir. 


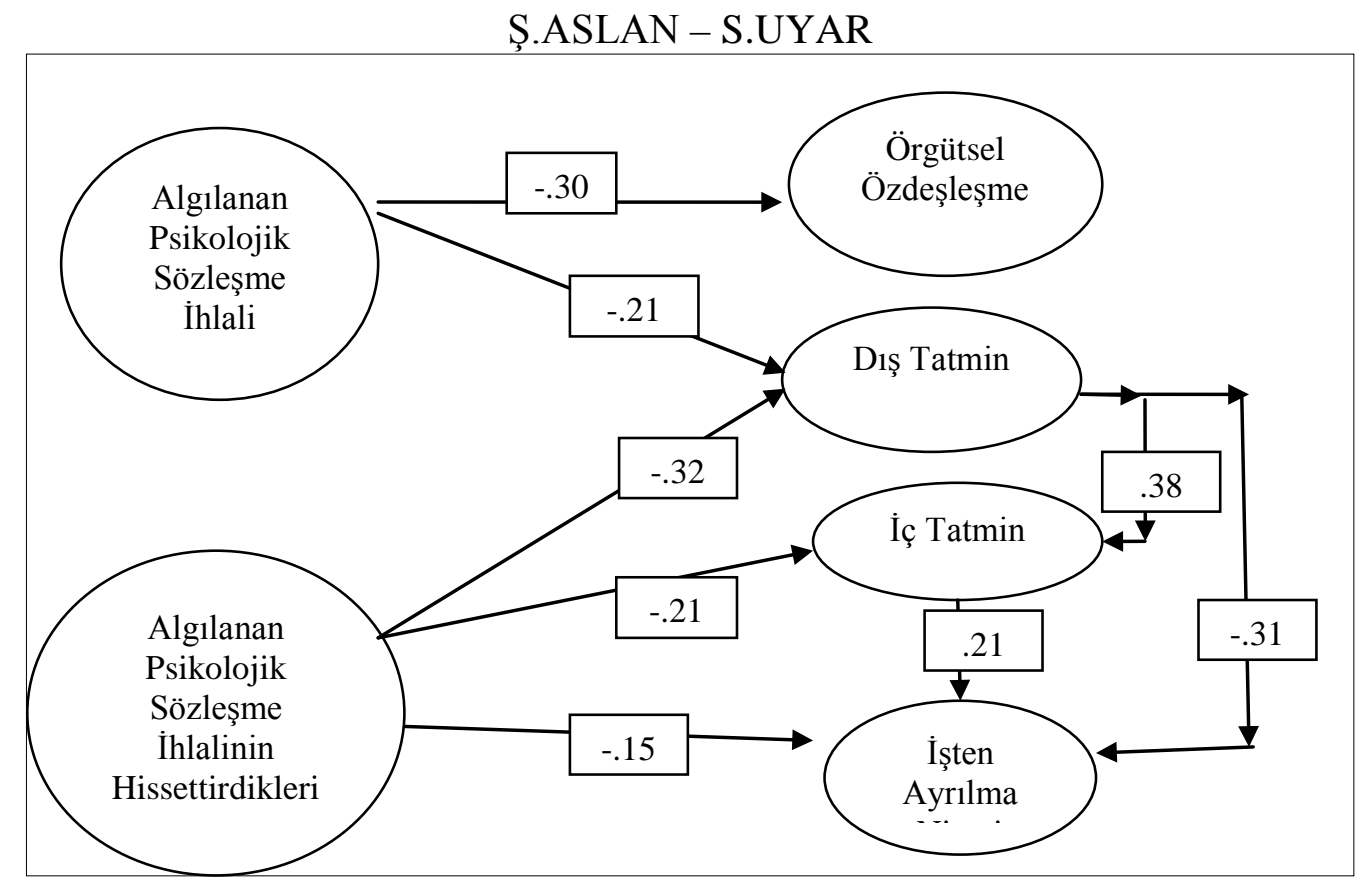

Şekil 3. Sonuç Modeli

Tablo 10. Uyum İyiliği İndeksleri: Yol Analizi

\begin{tabular}{|c|c|c|c|c|c|c|c|}
\hline $\begin{array}{c}\text { Uyum İyiliği } \\
\text { İndeksleri }\end{array}$ & $\chi 2 / \mathbf{d f}$ & NFI & NNFI & CFI & AGFI & GFI & RMSEA \\
\hline Model I & $115.07 / 6=19.178$ & .63 & .07 & .63 & .60 & .89 & .25 \\
\hline Model II & $7.72 / 4=1.93$ & .97 & .95 & .99 & .96 & .99 & .05 \\
\hline Model III & $8.78 / 6=1.46$ & .97 & .97 & .99 & .97 & .99 & .04 \\
\hline
\end{tabular}

Araştırmanın sonuçlarına göre, “algılanan psikolojik sözleşme ihlali”, “örgütsel özdeşleşme”(-.30) ve “dış tatmin” (-.21) ile negatif yönlü ilişkili bulunmuştur. "algılanan psikolojik sözleşme ihlalinin hissettirdikleri”, “ dış tatmin”, (-.32) “iç tatmin” (-.21)ve “işten ayrılma niyeti” (-.15)ile negatif yönlü anlamlı ilişkili bulunmuştur. Ancak "algılanan psikolojik sözleşme ihlali” ile “iç tatmin" ve “işten ayrılma niyeti” arasında anlamlı ilişki çıkmamıştır. Benzer şekilde “algılanan psikolojik sözleşme ihlalinin hissettirdikleri” ile “örgütsel özdeşleşme” arasında anlamlı ilişski bulunamamıştır. Araştırmada son olarak “dış tatmin” ile “iç tatmin”(.38) 
arasında anlamlı ve pozitif ilişki söz konusudur. "dış tatmin" ve "işten ayrılma niyeti” (-.31) arasında negatif yönlü anlamlı ilişkili bulunmuştur. Buna göre, H1, H3a, H4a, H4b ve H6 kabul edilmiştir. H2, H3b, H5 reddedilmiştir.

\section{SONUÇ VE TARTIŞMA}

Araştırmanın sonuçlarına göre, "algılanan psikolojik sözleşme ihlali”, “örgütsel özdeşleşme” ve “dış tatmin” ile negatif yönlü ilişkili bulunmuştur. "algılanan psikolojik sözleşme ihlalinin hissettirdikleri”, “ dış tatmin”, “iç tatmin” ve “işten ayrılma niyeti” ile negatif yönlü anlamlı ilişkili bulunmuştur. Ancak "algılanan psikolojik sözleşme ihlali” ile “iç tatmin” ve "işten ayrılma niyeti” arasında anlamlı ilişki çıkmamıştır. Benzer şekilde “algılanan psikolojik sözleşme ihlalinin hissettirdikleri” ile “örgütsel özdeşleşme” arasında anlamlı ilişki bulunamamıştır. Araştırmada son olarak “dış tatmin” ile “iç tatmin” arasında anlamlı ve pozitif ilişki söz konusudur. “dış tatmin” ve "işten ayrılma niyeti” arasında negatif yönlü anlamlı ilişkili bulunmuştur.

Araştırmanın sonuçlarından biri, psikolojik sözleşme ihlali ile örgütsel özdeşleşme arasındaki ilişkinin negatif yönlü olduğu şeklindedir. Bulunan sonuç, literatürde benzer yaklaşımlarla desteklenmektedir. Epitropaki’nin (2013: 81) yaptı̆̆ı araştırmaya göre örgütte psikolojik sözleşmenin ihlali örgütsel özdeşleşmeyi azaltmaktadır.

Psikolojik sözleşme ihlalinin hissettirdikleri ile iç ve dış iş tatmini; psikolojik sözleşme ihlali ile dış iş tatmini arasında negatif yönlü bir ilişkili tespit edikmiştir. Didikli ve Bayraktaroğlu' na (2013: 190) göre psikolojik sözleşmenin ihlâl edilmesi durumunda işgörenlerin verdikleri yaygın tepkilerden biri iş tatminindeki azalma olmaktadır. İşgörenin işe ilişkin aldığı ödüller ile sunduğu katkıya biçtiği değer arasındaki algıladığı uyum 


\section{S.ASLAN - S.UYAR}

ne kadar fazla ise iş tatmin düzeyi o nispette yüksek; işgörenin bu konudaki algıladığı uyumsuzluk ne kadar fazla ise iş tatmin düzeyi de o nispette düşük olmaktadır (Özgen ve Özgen, 2010: 4; Oshagbemi, 2003: 12111215).

Araştırma sonucunda ulaşılan bir diğer sonuç, psikolojik sözleşme ihlalinin hissettirdikleri ile işten ayrılma arasında negatif yönlü anlamlı bir ilişki olmasıdır. Çalışanların sözleşmenin ihlal edildiği yönünde güçlü inanışlara sahip olması, işten ayrılma da dâhil olmak üzere negatif tutum ve davranışlara yönelmelerine neden olmaktadır (Seçkin, 2011: 24). Psikolojik sözleşme ihlâli, yazılı olmayan bir sözleşmenin ihlâli olsa da işgörenlerin tutum ve davranışları üzerine önemli etkide bulunmaktadır (Turnley ve Feldman, 1999: 376).

Araştırma sonucunda psikolojik sözleşme ihlali ile işten ayrılma niyeti arasında anlamlı bir ilişki bulunamamasına karşın Büyükyılmaz ve Çakmak'ın (2014: 592) yapmış oldukları araştırmada algılanan psikolojik sözleşme ihlalinin işten ayrılma niyetini artırıcı bir etkisi olduğu bulunmuştur. Benzer bir çalışmada da psikolojik sözleşme ihlali ile işten ayrılma niyeti arasında düşük düzeyli ve pozitif ilişki bulunmuştur (Özgen ve Özgen, 2010: 14). Bununla beraber psikolojik sözleşme ihlalinin hissettirdikleri ile örgütsel sözleşme arasında da herhangi bir ilişkiye rastlanmamıştır. $\mathrm{Bu}$ araştırma sonucunda ulaşılan diğer bir sonuç da iş tatmini ile işten ayrılma niyeti arasında negatif yönlü bir ilişki olduğu şeklindedir. Çalışanların çalıştıkları işyerinde iş tatminine sahip olmaları; onların işten ayrılma niyetlerini azaltacak bununla birlikte işgücü kayıları, devir oranları ve devamsızlıklar azalmış olacaktır (Yücel ve Demirel, 2013:171). Çünkü iş tatmini işten ayrılma niyeti gibi olumsuz tepkilerin belirleyişi olmaktadır (Rusbelt vd.,1988:599). Bununla birlikte ișe devam 
Dokuz Eylül Üniversitesi İktisadi ve İdari Bilimler Fakültesi Dergisi Cilt:33, Sayı:1, Yll:2018, ss. 1-38

konusunda sorun yaşamakta, örgütten ayrılmaya daha çok meyil göstermektedirler (Robbins, 1998: 160).

Sağlık çalışanlarının algısının psikolojik sözleşmenin ihlal edildiği yönünde olması çalışanların tutum ve davranışlarında özellikle de örgüt çıkarlarının aleyhinde değişiklikler ortaya çıkmaktadır. Böylelikle psikolojik sözleşme beraberinde birçok faktörü de etkileyen kilit bir kavram olmaktadır. Çünkü işgören ile işveren arasındaki ortaya çıkabilecek sorunlara çözüm olabilecek bir unsurdur.Çalışanın işinden, kurumundan ve yönetim anlayışından memnuniyeti olarak tanımlanan iş tatmini (Yılmazer, 2005: 421) aynı zamanda çalıştığ1 örgütten ayrılma niyetine neden olmaktadır (Rusbelt vd.,1988: 599).İş tatmini iş görenin işle alakalı bilgi sahibi olmaya başladıkça gelişmekte ve iş görenin işle ilgili beklediği istekleri elde edememesi durumunda da azalmaktadır (Özler ve Ünver, 2012: 333). Turnley ve Feldman’a (2000: 27) göre psikolojik sözleşme ihlali iş görenin tatminsizliğini tetiklemektedir.

Araştırmada zaman ve maliyet kısıtları nedeniyle dört bölge ile sınırlı kalınmıştır. Araştırmamızdaki katılımcı sayısı da araştırmanın bir sınırlılığını oluşturmaktadır. Daha fazla sağlık çalışanının katılımcı olarak dâhil edilmesi ile sektöre katkı sağlayıcı sonuçlara ulaşılabilir. Ayrıca söz konusu değişkenlerdeki ilişkiye bakılırken örgüt kültürü ve örgütsel bağlılık gibi faktörlerin de aracı değişken olarak kullanılması ileriki araştırmalar için öngörülmektedir.

\section{KAYNAKÇA}

AÇIKALIN, C., (2011), "İçsel ve Dışsal Doyumun Örgütsel Bağlılığa Etkisi: Eskişehir Üretim Sektörü Örneği”, Dumlupınar Üniversitesi Sosyal bilimler Enstitüsü Dergisi, 31, 237-254. 


\section{S.ASLAN - S.UYAR}

ALEXANDER, J.A., BLOOM, J.R., NUCHOLS, B.A. (1994), “Nursing Turnover and Hospital Efficiency: An Organization-Level Analysis", Industrial Relations, 33, 505-520.

ALTUNIŞIK, R., COŞKUN, R., BAYRAKTAROĞLU, S., YILDIRIM, E. (2012), "Sosyal Bilimlerde Araştırma Yöntemleri SPSS Uygulamalı", Sakarya Kitapevi, Yedinci Baskı, İstanbul.

ARI, G.S., BAL, H., BAL, E.Ç. (2010),“İșe Bağlılığın Tükenmişlik ve İşten Ayrılma Niyeti İlişkisindeki Aracılık Etkisi: Yatırım Uzmanları Üzerinde Bir Araştırma", Süleyman Demirel Üniversitesi İktisadi ve İdari Bilimler Fakültesi Dergisi, 15(3), 143-166.

ASELAGE, J., EISENBERGER, R. (2003), 'Perceived Organizational Support and Psychological Contracts: A Theoretical Integration”, Journal of Organizational Behavior, 24, 491-509.

ASHFORTH B.E., MAEL F.(1989), "Social Identity Theory and the Organization”, The Academy of Management Review , 14(1), 20-39.

AYYILDIZ, H., CENGİZ, E., USTASÜLEYMAN, T. (2006), “Üretim ve Pazarlama Bölüm Çalışanları Arası Davranışsal Değişkenlerin Firma Performansı Üzerine Etkisine İlişkin Yapısal Bir Model Önerisi”, Muğla Üniversitesi Sosyal Bilimler Enstitüsü Dergisi (ILKE), 17,11-12.

BAGOZZI, R.P., YI, Y.(1988),“On the Evaluation of Structural Equation Models”, J. Acad. Marketing Sci. 16(1), 74-94.

BARTLETT, K.R. (1999),“The Relationship Between Training and Organizational Commitment in The Health Care Field. The Degree of Doctor of Philosophy”, The University of Illinois, Urbana.

BAYDUR H, ESER E. (2006),“Uygulama: Yaşam Kalitesi Ölçeklerinin Psikometrik Çözümlenmesi”, Sağllkta Birikim, 1(2), 99-123.

BAYRAK K. S.(2006), “İş Tatmini ve Örgütsel Bağlılığın İncelenmesine Yönelik Bir Araştırma”, İktisadi ve İdari Bilimler Dergisi, 20(1), 291-317.

BAYCAN, A. (1985), “An Analysis of Several Aspects of Job Satisfaction Between Diffrent Occupational Groups”, Bogaziçi Üniversitesi Yayınlanmamış Yüksek Lisans Tezi, İstanbul. 
BROWN, S.P., CRON, W.L., SLOCUM, J.W.(1998),“Effects of Trait Competitiveness and Perceived intraorganizational Competition on Salesperson Goal Setting and Performance”, Journal of Marketing, 62, 8898.

BUCHANAN II,B.(1974),“Building Organizational Commitment: The Socialization of Managers in Work Organizations" Administrative Science Quarterly, 19(4), 533-546.

BUICK, I., THOMAS, M.(2001),"Why Do Middle Managers in Hotels Burn Out?”, International Journal of Contemporary Hospitality Management, 13 (6), 304-309.

BÜYÜKYILMAZ, O., ÇAKMAK, A.F. (2014),“İlişkisel ve İşlemsel Psikolojik Sözleşmede Algılanan İhlalin İşten Ayrılma Niyeti ve Algılanan Örgütsel Destek Üzerindeki Etkisi”, Ege Akademik Bakış, 14(4), 583-596.

CHAMBEL, M.J., OLIVEIRA F.(2010),“Breach of Psychological Contract and the Development of Burnout and Engagement: A Longitudinal Study Among Soldiers on a Peacekeeping Mission”, Military Psychology, 22, 110-127.

CHAU, P. (1997),"Reexamining A Model of Evaluation Information Center Success Using A Structural Equation Modeling Approach”, Decision Sciences, 28, 309-334.

CHROBOT-MASON, D. L. (2003), "Keeping the PromisePsychological Contract Violations for Minority Employees", Journal of Managerial Psychology, 18(1), 22-45.

CİHANGİROĞLU, N., ŞAHİN, B. (2010), "Organizasyonlarda Önemli Bir Fenomen: Psikolojik Sözleşme", Zonguldak Karaelmas Üniversitesi Sosyal Bilimler Dergisi, 6(11), 1-16.

COTTON, J.L.,TUTTLE, J.M. (1986), “Employee Turnover: A MetaAnalysis and Review with Implications for Research", The Academy of Management Review, 11(1), 55-70.

ÇAKIR, Ö. (2001), “İşe Bağlılık Olgusu ve Etkileyen Faktörler” Ankara: Seçkin Yayınları. 


\section{S.ASLAN - S.UYAR}

DENIZ, M. (2005) "Bir Tutum Çeşidi Olarak İş Doyumu”, Örgütsel Davranış Boyutlarından Seçmeler, Ed. Mehmet TíKİCİ, Ankara, Nobel Yayını.

DOĞAN, S., DEMİRAL, Ö. (2009),“Örgütsel Bağlılığın Sağlanmasında Personel Güçlendirme ve Psikolojik Sözleşmenin Etkisine İlişkin Bir Araştırma”, Erciyes Üniversitesi İktisadi ve İdari Bilimler Fakültesi Dergisi, 32, 47-80.

DİDİKLİ, A., BAYRAKTAROĞLU, S.(2013),"Psikolojik Sözleşme İle İş Tatmini İlişkisi: Bir Örnek Olay Çalışması”, 1. Örgütsel Davranış Kongresi Bildiriler Kitabı, Sakarya Üniversitesi Işsletme Fakültesi,Sakarya,188-193.

DİKİCI, A.M., (2005), "Dönüştürücü Liderliğin İş Tatminine EtkisiGAP Bölgesi ve Çevre İllerde Bir Uygulama", Basılmamış Doktora Tezi, Sakarya Üniversitesi Sosyal Bilimler Enstitüsü.

DUTTON J.E., DUKERICH J.M., HARQUAUIL C.V. (1994), “Organizational Images and Member Identification”, Administrative Science Quarterly, 39(2), 239-263.

EPITROPAKI, O. (2013),“A Multi-Level Investigation of Psychological Contract Breach and Organizational Identification Through the Lens of Perceived Organizational Membership: Testing A Moderated-Mediated Model”, Journal of Organizational Behavior, 34, 65-86.

FORNELL, C.,LARCKER, D. F. (1981),“Evaluating Structural Equation Models with Unobservable Variables and Measurement Error”, Journal of Marketing Research, 18, 39-50.

FRED, M., BLAKE E.A.(1992),“ Alumni and Their Alma Mater: A Partial Test of The Reformulated Model of Organizational Identification”, Journal of Organizational Behavior, 13,103-123.

FREESE, C., SCHALK, R. (1996), "Implications of Differences in Psychological Contracts for HRM", European Journal of Work and Organizational Pscyhology, 5 (4), 1996, 501-509.

HALL, D.T., SCHNEIDER B., NYGREN, H.T. (1970),“Personal Factors in Organizational Identification”, Administrative Science Quarterly, 15, 176-190. 
Cilt:33, Sayl:1, Yll:2018, ss. 1-38

HOM, P.W., CARANIKAS-WALKER, F., PRUSSIA, G.E.,GRIFFETH, R.W.(1992),“A Meta-Analytical Structural Equations Analysis of a Model of Employee Turnover”, Journal of Applied Psychology, 77(6), 890-909.

HINKIN, T. (1995),“A Review of Scale Development Practices in The Study of Organisations”, Journal of Management, 21(5), 967-988.

HU, L., BENTLER, P.M. (1999),“Cut off criteria for fit indexes in covariance structure analysis: Conventional criteria versus new alternatives”, Structural Equation Modeling: A Multidisciplinary Journal, 6(1), 1-55.

HOYT, C.L. ve BLASCOVICH, J., (2003), "Transformational and Transactional Leadership in Virtual and Physical Environments”, Small Group Research, 34 (6), 678-715.

HUI, S. (2003),“Revision of Genetic Regulatory Models Using Structural Equation Modeling/Path Analysis”, Internet Address: http://zencaroline.blogspot.com/2007/06/compositereliability.html, Date of Access: 03.09.2010.

HWANG, I., KUO, J. (2006),"Effects of Job Satisfaction and Perceived Alternative Employment Opportunities on Turnover Intention-An Examination of Public Sector Organizations” Journal of American Academy of Business, Cambridge, 8(2), 254-259.

KALDIRIMCI, N. (1987),"Motivasyon için anahtar bir kavram: psikolojik sözleşme”, Erciyes Üniversitesi Sosyal Bilimler Enstitüsü Dergisi, 1(1), 113-128.

KNIGHTS, J.A., KENNEDY, B.J.(2005),“Psychological Contract Violation: Impacts on Job satisfaction and Organizational Commitment Among Australian Senior Public Servants”, Applied H.R.M. Research, 10(2), 57-72.

KÖK, B.S. (2006), “İş Tatmini ve Örgütsel Bağl1lı̆gn İncelenmesine Yönelik Bir Araştırma”, Íktisadi ve İdari Bilimler Dergisi, 20(1), 291-317.

LEE, G.J. ve FALLER, N. (2005), “Transactional and Relational Aspects of the Psychological Contracts of Temporary Workers", South African Journal of Psychological, 35(4), 831-847. 


\section{S.ASLAN - S.UYAR}

LEVINSON, H.(1965), "Reciprocration:The relationship between Man and Organization”, Administrative Science Quarterly, 9(4).

LI, S.R., RAGU-NATHAN T.S., RAGU-NATHAN B. (2005), "Development and validation of A Measurement Instrumentfor Studying Supply Chain Management Practices”, Journal of Operations Management, 23, 618-641.

LOCKE, E.A., HENNE, D. (1986), “Work Motivation Theories”, In C. Cooper \& I. Robertson (Eds.), International Review of Industrial and Organizational Psychology. Chichester, England: Wiley Ltd., 1-35.

LUTHANS F. (1994), “Organizational Behavior”, Newyork: McGrawHill, Inc.

MACDONALD, S., MACLNTYRE, P. (1997), “The Generic J ob Satisfaction Scale: Scale Development and Its Correlates”, Employee Assistance Quarterly, 13(2), 1-16.

MAEL, F. (1986),"Latitude for Lieutenancy: The Exchange Component Od The Vertical Dyad Linkage Model of Leadership", Unpublished Master's Thesis, Wayne State University, Detroit.

MAEL, F.A.,ASHFORTH,B.E.(1995),“Loyal from Day One: Biodata, Organizational Identification, and Turnover among Newcomers”, Personnel Psychology, 48, 309-333.

MILLER, V.D., ALLEN M., CASEY, M.K., JOHNSON, J.R. (2000), "Reconsidering the Organizational Identification Questionnaire", Management Communication Quarterly, 13 (4), 626-658.

MIMAROĞLU, H.(2008),"Psikolojik Sözleşmenin Personelin Tutum ve Davranışlarına Etkileri: Tıbbi Satış Temsilcileri Üzerinde Bir Araştırma”, Yayınlanmamış Doktora Tezi. Adana: Çukurova Üniversitesi Sosyal Bilimler Enstitüsü.

MOBLEY, W.H.(1982),“Employee Turnover: Causes, Consequences and Control”, Massachusetts: Addison-Wesley.

MORHEAD, G. ve GRIFFIN, R.W. (1996),“Organizational Behavior Managing People and Organizations, Five Edition”, Houghton Mifflin Comp. Boston. 
MORRISON, E.W., ROBINSON, S.L. (1997), “When Employees Feel Betrayed: A Model of How Psychological Contract Violation Develops”, Academy of Management Review, 22(1), 226-256.

NAEEM, A.T., IHSAN, F., MAHMOOD, Z. (2014). "The Study of Organizational Justice, Violation of Psychological Contract and its Effect on Job Satisfaction in Paints Industry of Pakistan. International Journal of Academic Research in Business and Social Sciences December 2014, 4(12), 244-458.

ORBAY, N.T. (2008), “Hastanelerde Hemşirelerin İşte Kalma ve İşten Ayrılma Niyetlerini Etkileyen Faktörlerin Belirlenmesi”, (Yayımlanmamış Yüksek Lisans Tezi). Haliç Üniversitesi Sağlık Bilimleri Enstitüsü, İstanbul.

OSHAGBEMİ, T. (2003), "Personal Correlates of Job Satisfaciton: Empirical Evidence from UK Universities”, International Journal of Social Economics, 30(12), 1210-1232.

ÖKTEN, S.S. (2008),“Güçlendirmenin İş Tatmini ve İşten Ayrılma Niyeti Üzerine Etkisinde Kalite Kültürünün Ara Değişken Olarak İncelenmesi”, Gebze İleri teknoloji Enstitüsü Sosyal Bilimler Enstitüsü, Yüksek Lisans Tezi, Gebze, 38.

ÖRÜCÜ， E.， ÖZAFŞARLIOĞLU， S. (2013),“Örgütsel Adaletin Çalışanların İşten Ayrılma Niyetine Etkisi: Güney Afrika Cumhuriyetinde Bir Uygulama”, Mustafa Kemal Üniversitesi Sosyal Bilimler Enstitüsü Dergisi, 10(23), 335-358.

ÖZDEMİR, H., YAYLI, A. (2014),“Çalışanın Örgütsel Bağgl1lı̆̆1, Performansı ve İşten Ayrılma Niyeti Arasındaki İlişkinin Belirlenmesine Yönelik Bir Araştırma”, Journal of Recreation and Tourism Research (Jrtr), 1 (1), 48-58.

ÖZDEVECİOĞLU, M. (2004), “Algılanan Örgütsel Desteğin İssten Ayrılma Niyeti Üzerindeki Etkileri”, Amme İdaresi Dergisi, 37(4), 97-115.

ÖZGEN, M.H., ÖZGEN, H., (2010), "Psikolojik Sözleşme ve Boyutlarının İş Tatmini, Örgütsel Bağlılık ve İşten Ayrılma Niyetine Etkileri: Tıbbi Satış Temsilcileri Üzerinde Bir Araştırma, Çukurova Üniversitesi Sosyal Bilimler Enstitüsü Dergisi, 19(1), 1-19. 


\section{S.ASLAN - S.UYAR}

ÖZLER, D.E., (2012), "Psikolojik Sözleşmenin İş Tatmini Üzerindeki Etkisini Belirlemeye Yönelik Bir Araştırma", Süleyman Demirel Üniversitesi İktisadi ve İdari Bilimler Fakültesi Dergisi, 17(2), 325-351.

PETERSON, R. A. (1994),“A Meta-Analysis of Cronbach’s Coefficient Alpha”, Journal of Consumer Research, 21: 381-391.

PETRAY-GUILLARD， D.(2008),“Union Discourse and Perceived Violation of Contract: A Social Contract- Based Approach”, Industrial Relations, 63(3), 479-501.

POLAT, M., MEYDAN, C.H. (2010),“Örgütsel Özdeşleşmenin Sinizm ve İşten Ayrılma Niyeti İle İlişkisi Üzerine Bir Araştırma”, Kara Harp Okulu Savunma Bilimleri Enstitüsü Dergisi, 145-172.

PORTNEY LG, WATKINS MP. (1993), Foundation of Clinical Research. 42-73.

ROBINSON, S.L.(1996),“Trust and Breach of the Psychological Contract”, Administrative Science Quarterly, 41(4), 574-599.

ROBBINSS, S. P., (1998), "Organizational Behavior: Concepts, Controversies, Applications”, Eighth Edition (International Edition), Prentice Hall-International, New Jersey.

ROBBINSS, S.P.,JUDGE, T.A. (2012),“Örgütsel Davranış”, Ed.: İnci Erdem, Nobel: Ankara.

RUSBELT, C.E., FARRELL, D., ROGERS, G., and MAINOUS, A. G. (1988), “Impact of Exchange Variables on Exit, Voice, Loyalty and Neglect: An Integrative Model of Responses to Decline Job Satisfaction”, Academy of Management Journal, 31(2), 599-627.

ROUSSEAU, D. M. (1998), "Why Workers Still Identify with Organizations”, Journal of Organizational Behavior, 19, 217-233.

SANDRA, R.,ELIZABETH W.M. (2000), “The Development of Psychological Contract Breach and Violation: A Longitudinal Study", Journal of Organizational Behavior, 21, 525-546.

SCHEIN, E. H., (1980), “Organizational Psychology”, 3rd Edition, New Jersey, Prentice-Hall, 1980. 
SCHERMELLEH-ENGEL, K., MOOSBRUGGER, H., MÜLLER, H., (2003), "Evaluating the Fit of Structural Equation Models: Tests of Significance and Descriptive Goodness-of-Fit Measures", Methods of Psychological Research Online, 8(2), 23-74,

SCHNEIDER, B., SNYDER, R. (1975), "Some Relationship Between Job Satisfaction and Organizational Climate", Journal of Applied Psychology, 60(3), 318-328.

SINGH, R., (1998), “ Redefining Psychological Contractswith the U.S. Work Force: A Critical Task for Strategic Human Resource Management Planners in the 1990s”, Human Resource Management, 37(1), 61-69.

SEÇKİN, Z. (2011), "Psikolojik Sözleşme”, Atlas Akademi, Konya.

STEIGER, J. H. (1990), "Structural Model Evaluation and Modification: An Interval Estimation Approach”, Multivariate Behavioral Research, 25, 173-180.

ŞAHIN, F. (2011), “Lider-Üye Etkileşimi İle İşten Ayrılma Niyeti Arasındaki İlişki Üzerinde Cinsiyetin Etkisi”, Ege Akademik Bakış, 11(2), 277-288.

TEOMAN, D. D. (2007),“Performans Değerlendirme Sürecinde Oluşan Adalet Algısı, Bu Algının İç, Dış ve Sosyal Ödüllerle Olan İlişkisinin İşten Ayrılma Niyeti'ne Olan Etkisi”, Yayınlanmamış Yüksek Lisans Tezi, İstanbul Üniversitesi, Sosyal Bilimler Enstitüsü, İstanbul.

TETT, R.P.,MEYER, J.P. (1993),“Job Satisfaction, Organizational Commitment, Turnover Intention, and Turnover: Path Analyses Based on Meta Analytic Findings”, Personnel Psychology, 46, .259-293.

TURNLEY, H. W., FELDMAN, C. D., (1999), “A Discrepancy Model of Psychological Contract Violations", Human Resource Management Review, 9(3), 367-386.

TURNLEY, H. W., FELDMAN, C. D., (2000), "ReExamining The Effects of Psychological Contract Violations: Unmet Expectations and Job Dissatisfaction As Mediators”, Journal of Organizational Behavior, 21(1), 25-42. 


\section{S.ASLAN - S.UYAR}

WALKER, A., HUTTON, D. M. (2006), “ The Application of the Psychological Contract to Workplace Safety”, Journal of Safety Research, 37(5), 433-441.

WAYNE N.J., SHORE L.M., LIDEN R.C. (1997), "Perceived Organizational Support and Leader-Member Exchange, A Social Exchange Perspective”, Academy of Management Journal, 40, 82-111.

WEISS D.J., DAWIS R.V., ENGLAND G.W.(1967), "Manual for the Minnesota Satisfaction Questionnaire", Minnesota Studies in Vocational Rehabilitation, 22, 120.

WEISBERG, J. (1994),“Measuring Workers’ Burnout and Intention to Leave”, International Journal of Manpower, 15(1), 4-14.

YILMAZER, A.(2005),“İşletme Yönetiminde Empatik İletişim ve İşgücü Verimliliğine Etkisi: Federal Mogul Sapanca Segman ve Gömlek Üretim Tesisleri A.Ş. Örneği. 2. Kobiler ve Verimlilik Kongresi”, İstanbul Kültür Üniversitesi, İstanbul.

YÜCEL, İ. DEMİREL, Y.(2013),"Mevcut İş Alternatiflerinin İş Tatmini ve İşten Ayrılma İlişkisi Üzerine Etkisi: Başka Bir Yol Daha Olmalı", Atatürk Üniversitesi İktisadi ve İdari Bilimler Dergisi, 27(2), 159-177.

YÜCENUR, G.N., DEMIREL, N.Ç., CEYLAN, C., DEMİREL, T. (2011), "Hizmet Değerinin Müşterilerin Davranışsal Niyetleri Üzerindeki Etkisinin Yapısal Eşitlik Modeli İle Ölçülmesi”, Doğuş Üniversitesi Dergisi, 12 (1), 156-168.

ZHAO, H., WAYNE, S. J., GLIBKOWSKI, B. C., BRAVO, J. (2007), "The Impact of Psychological Contract Breach on Work-related Outcomes: A Meta-Analysis”, Personel Psychology, 60, 647-680. 